4

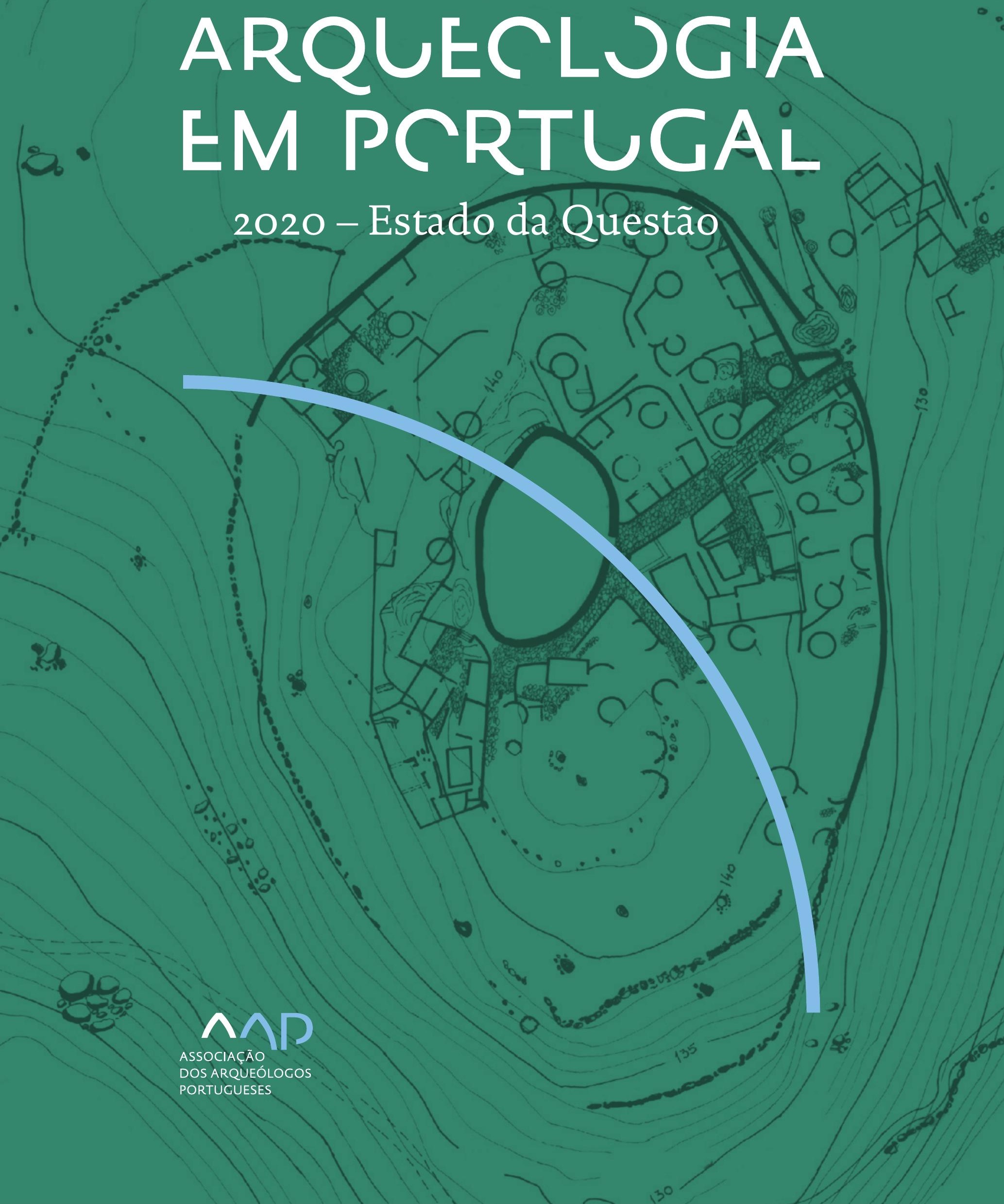


Coordenação editorial: José Morais Arnaud, César Neves e Andrea Martins Design gráfico: Flatland Design

AAP - ISBN: 978-972-9451-89-8

CITCEM - ISBN: 978-989-8970-25-1

Associação dos Arqueólogos Portugueses e CITCEM

Lisboa, 2020

O conteúdo dos artigos é da inteira responsabilidade dos autores. Sendo assim a Associação dos Arqueólogos Portugueses declina qualquer responsabilidade por eventuais equívocos ou questões de ordem ética e legal.

Desenho de capa:

Planta do castro de Monte Mozinho (Museu Municipal de Penafiel).

\section{$\hat{\wedge} \mathrm{P}$}

DOS ARQUEÓLOGOS PORTUGUESES

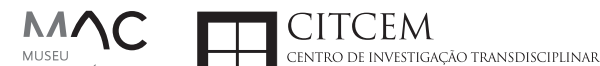
MUSEU
ARQUELLÓGICO
DO CARMO
U.PORTO

FLUP FACULDADE DE LETRAS
UNIVERSIDADE DO PORTO

Apoio

EC para a Ciência 


\section{Índice}

15 Prefácio

José Morais Arnaud

\section{Historiografia e Teoria}

17 Território, comunidade, memória e emoção: a contribuição da história da arqueologia (algumas primeiras e breves reflexões)

Ana Cristina Martins

25 Como descolonizar a arqueologia portuguesa?

Rui Gomes Coelho

41 Arqueologia e Modernidade: uma revisitação pessoal e breve de alguns aspetos da obra homónima de Julian Thomas de 2004

Vítor Oliveira Jorge

57 Dados para a História das Mulheres na Arqueologia portuguesa, dos finais do século XIX aos inícios do século XX: números, nomes e tabelas

Filipa Dimas / Mariana Diniz

73 Retractos da arqueologia portuguesa na imprensa: (in)visibilidades no feminino

Catarina Costeira / Elsa Luís

85 Arqueologia e Arqueólogos no Norte de Portugal Jacinta Bugalhão

101 Vieira Guimarães (1864-1939) e a arqueologia em Tomar: uma abordagem sobre o território e as gentes

João Amendoeira Peixoto / Ana Cristina Martins

115 Os memoráveis? A arqueologia algarvia na imprensa nacional e regional na presente centúria (2001-2019): características, visões do(s) passado(s) e a arqueologia

enquanto marca

Frederico Agosto / João Silva

129 A Evolução da Arqueologia Urbana e a Valorização Patrimonial no Barlavento Algarvio: Os casos de Portimão e Silves

Artur Mateus / Diogo Varandas / Rafael Boavida

\section{Gestão, Valorização e Salvaguarda do Património}

145 O Caderno Reivindicativo e as condições de trabalho em Arqueologia Miguel Rocha / Liliana Matias Carvalho / Regis Barbosa / Mauro Correia / Sara Simões / Jacinta Bugalhão / Sara Brito / Liliana Veríssimo Carvalho / Richard Peace / Pedro Peça / Cézer Santos

155 Os Estudos de Impacte Patrimonial como elemento para uma estratégia sustentável de minimização de impactes no âmbito de reconversões agrícolas Tiago do Pereiro

165 Salvaguarda de Património arqueológico em operações florestais: gestão e sensibilização Filipa Bragança / Gertrudes Zambujo / Sandra Lourenço / Belém Paiva / Carlos Banha / Frederico Tatá Regala / Helena Moura / Jacinta Bugalhão / João Marques / José Correia / Pedro Faria / Samuel Melro

179 Os valores do Património: uma investigação sobre os Sítios Pré-históricos de Arte Rupestre do Vale do Rio Côa e de Siega Verde José Paulo Francisco 
189 Conjugando recursos arqueológicos e naturais para potenciar as visitas ao Geoparque Litoral de Viana do Castelo (Noroeste de Portugal)

Hugo A. Sampaio / Ana M.S. Bettencourt / Susana Marinho / Ricardo Carvalhido

203 Áreas de Potencial Arqueológico na Região do Médio Tejo: Modelo Espacial Preditivo Rita Ferreira Anastácio / Ana Filipa Martins / Luiz Oosterbeek

223 Património Arqueológico e Gestão Territorial: O contributo da Arqueologia para a revisão do PDM de Avis

Ana Cristina Ribeiro

237 A coleção arqueológica do extinto Museu Municipal do Porto - Origens, Percursos e Estudos

Sónia Couto

251 Valpaços - uma nova carta arqueológica

Pedro Pereira / Maria de Fátima Casares Machado

263 Arqueologia na Cidade de Peniche

Adriano Constantino / Luís Rendeiro

273 Arqueologia Urbana: a cidade de Lagos como caso de Estudo Cátia Neto

285 Estratégias de promoção do património cultural subaquático nos Açores. O caso da ilha do Faial

José Luís Neto / José Bettencourt / Luís Borges / Pedro Parreira

297 Carta Arqueológica da Cidade Velha: Uma primeira abordagem

Jaylson Monteiro / Nireide Tavares / Sara da Veiga / Claudino Ramos / Edson Brito /

Carlos Carvalho / Francisco Moreira / Adalberto Tavares

311 Antropologia Virtual: novas metodologias para a análise morfológica e funcional Ricardo Miguel Godinho / Célia Gonçalves

\section{Didáctica da Arqueologia}

327 Como os projetos de Arqueologia podem contribuir para uma comunidade culturalmente mais consciente Alexandra Figueiredo / Claúdio Monteiro / Adolfo Silveira / Ricardo Lopes

337 Educação Patrimonial - Um cidadão esclarecido é um cidadão ativo! Ana Paula Almeida

351 A aproximação da Arqueologia à sala de aula: um caso de estudo no $3^{\circ}$ ciclo do Ensino Básico Luís Serrão Gil

363 Arqueologia 3.o - Pensar e comunicar a Arqueologia para um futuro sustentável Mónica Rolo

377 “Conversa de Arqueólogos" - Divulgar a Arqueologia em tempos de Pandemia Diogo Teixeira Dias

389 Escola Profissional de Arqueologia: desafios e oportunidades Susana Nunes / Dulcineia Pinto / Júlia Silva / Ana Mascarenhas

399 Os Museus de Arqueologia e os Jovens: a oferta educativa para o público adolescente Beatriz Correia Barata / Leonor Medeiros

411 O museu universitário como mediador entre a ciência e a sociedade: o exemplo da secção de arqueologia no Museu de História Natural e da Ciência da Universidade do Porto (MHNC-UP)

Rita Gaspar 
421 Museu de Lanifícios: Real Fábrica de Panos. Atividades no âmbito da Arqueologia Beatriz Correia Barata / Rita Salvado

427 Arqueologia Pública e o caso da localidade da Mata (Torres Novas) Cláudia Manso / Ana Rita Ferreira / Cristiana Ferreira / Vanessa Cardoso Antunes

431 Do sítio arqueológico ao museu: um percurso (também) didático Lídia Fernandes

447 Estão todos convidados para a Festa! E para dançar também... O projecto do Serviço Educativo do Museu Arqueológico do Carmo na $5^{\underline{a}}$ Edição da Festa da Arqueologia Rita Pires dos Santos

459 O “Clã de Carenque”, um projeto didático de arqueologia Eduardo Gonzalez Rocha

469 Mediação cultural: peixe que puxa carroça nas Ruínas Romanas de Troia Inês Vaz Pinto / Ana Patrícia Magalhães / Patrícia Brum / Filipa Santos

481 Didática Arqueológica, experiências do Projeto Mértola Vila Museu Maria de Fátima Palma / Clara Rodrigues / Susana Gómez / Lígia Rafael

\section{Arte Rupestre}

497 Os inventários de arte rupestre em Portugal Mila Simões de Abreu

513 O projeto FIRST-ART - conservação, documentação e gestão das primeiras manifestações de arte rupestre no Sudoeste da Península Ibérica: as grutas do Escoural e Maltravieso Sara Garcês / Hipólito Collado / José Julio García Arranz / Luiz Oosterbeek / António Carlos Silva / Pierluigi Rosina / Hugo Gomes / Anabela Borralheiro Pereira / George Nash / Esmeralda Gomes / Nelson Almeida / Carlos Carpetudo

523 Trabalhos de documentação de arte paleolítica realizados no âmbito do projeto PalæoCôa André Tomás Santos / António Fernando Barbosa / Luís Luís / Marcelo Silvestre / Thierry Aubry

537 Imagens fantasmagóricas, silhuetas elusivas: as figuras humanas na arte do Paleolítico Superior da região do Côa Mário Reis

$55^{1}$ Os motivos zoomórficos representados nas placas de tear de Vila Nova de São Pedro (Azambuja, Portugal) Andrea Martins / César Neves / José M. Arnaud / Mariana Diniz

571 Arte Rupestre do Monte de Góios (Lanhelas, Caminha). Síntese dos resultados dos trabalhos efectuados em 2007-2009 Mário Varela Gomes

599 Gravuras rupestres de barquiformes no Monte de S. Romão, Guimarães, Noroeste de Portugal Daniela Cardoso

613 Círculos segmentados gravados na Bacia do Rio Lima (Noroeste de Portugal): contributos para o seu estudo Diogo Marinho / Ana M.S. Bettencourt / Hugo Aluai Sampaio

631 Equídeos gravados no curso inferior do Rio Mouro, Monção (NW Portugal). Análise preliminar Coutinho, L.M. / Bettencourt, A.M.S / Sampaio, Hugo A.S

645 Paletas na Arte Rupestre do Noroeste de Portugal. Inventário preliminar Bruna Sousa Afonso / Ana M. S. Bettencourt / Hugo A. Sampaio 


\section{Pré-História}

661 O projeto Miño/Minho: balanço de quatro anos de trabalhos arqueológicos Sérgio Monteiro-Rodrigues / João Pedro Cunha-Ribeiro / Eduardo Méndez-Quintas / Carlos Ferreira / Pedro Xavier / José Meireles / Alberto Gomes / Manuel Santonja / Alfredo Pérez-González

677 A ocupação paleolítica da margem esquerda do Baixo Minho: a indústria lítica do sítio de Pedreiras 2 (Monção, Portugal) e a sua integração no contexto regional Carlos Ferreira / João Pedro Cunha-Ribeiro / Sérgio Monteiro-Rodrigues / Eduardo Méndez-Quintas / Pedro Xavier / José Meireles / Alberto Gomes / Manuel Santonja / Alfredo Pérez-González

693 O sítio acheulense do Plistocénico médio da Gruta da Aroeira Joan Daura / Montserrat Sanz / Filipa Rodrigues / Pedro Souto / João Zilhão

703 As sociedades neandertais no Barlavento algarvio: modelos preditivos com recurso aos SIG

Daniela Maio

715 A utilização de quartzo durante o Paleolítico Superior no território dos vales dos rios Vouga e Côa

Cristina Gameiro / Thierry Aubry / Bárbara Costa / Sérgio Gomes / Luís Luís / Carmen Manzano / André Tomás Santos

733 Uma perspetiva diacrónica da ocupação do concheiro do Cabeço da Amoreira (Muge, Portugal) a partir da tecnologia lítica Joana Belmiro / João Cascalheira / Célia Gonçalves

745 Novos dados sobre a Pré-história Antiga no concelho de Palmela. A intervenção arqueológica no sítio do Poceirão I

Michelle Teixeira Santos

757 Problemas em torno de Datas Absolutas Pré-Históricas no Norte do Alentejo Jorge de Oliveira

771 Povoamento pré-histórico nas áreas montanhosas do NO de Portugal: o Abrigo 1 de Vale de Cerdeira Pedro Xavier / José Meireles / Carlos Alves

783 Apreciação do povoamento do Neolítico Inicial na Baixa Bacia do Douro. A Lavra I (Serra da Aboboreira) como caso de estudo Maria de Jesus Sanches

797 O Processo de Neolitização na Plataforma do Mondego: os dados do Sector C do Outeiro dos Castelos de Beijós (Carregal do Sal)

João Carlos de Senna-Martinez / José Manuel Quintã Ventura / Andreia Carvalho / Cíntia Maurício

823 Novos trabalhos na Lapa da Bugalheira (Almonda, Torres Novas) Filipa Rodrigues / Pedro Souto / Artur Ferreira / Alexandre Varanda / Luís Gomes / Helena Gomes / João Zilhão

837 A pedra polida e afeiçoada do sítio do Neolítico médio da Moita do Ourives (Benavente, Portugal)

César Neves

857 Casal do Outeiro (Encarnação, Mafra): novos contributos para o conhecimento do povoamento do Neolítico final na Península de Lisboa.

Cátia Delicado / Carlos Maneira e Costa / Marta Miranda / Ana Catarina Sousa

873 Stresse infantil, morbilidade e mortalidade no sítio arqueológico do Neolítico Final/ Calcolítico ( $4^{\circ}$ e $3^{\circ}$ milénio a.C.) do Monte do Carrascal 2 (Ferreira do Alentejo, Beja) Liliana Matias de Carvalho / Sofia N. Wasterlain 
885 Come together: O Conjunto Megalítico das Motas (Monção, Viana do Castelo) e as expressões Campaniformes do Alto Minho Ana Catarina Basílio / Rui Ramos

899 Trabalhos arqueológicos no sítio Calcolítico da Pedreira do Poio Carla Magalhães / João Muralha / Mário Reis / António Batarda Fernandes

913 O sítio arqueológico de Castanheiro do Vento. Da arquitectura do sítio à arquitectura de um território João Muralha Cardoso

925 Estudo zooarqueológico das faunas do Calcolítico final de Vila Nova de São Pedro (Azambuja, Portugal): Campanhas de 2017 e 2018 Cleia Detry / Ana Catarina Francisco / Mariana Diniz / Andrea Martins / César Neves / José Morais Arnaud

943 As faunas depositadas no Museu Arqueológico do Carmo provenientes de Vila Nova de São Pedro (Azambuja): as campanhas de 1937 a 1967 Ana Catarina Francisco / Cleia Detry / César Neves / Andrea Martins / Mariana Diniz / José Morais Arnaud

959 Análise funcional de material lítico em sílex do castro de Vila Nova de S. Pedro (Azambuja, Portugal): uma primeira abordagem Rafael Lima

971 O recinto da Folha do Ouro 1 (Serpa) no contexto dos recintos de fossos calcolíticos alentejanos

António Carlos Valera / Tiago do Pereiro / Pedro Valério / António M. Monge Soares

\section{Proto-História}

987 Produção de sal marinho na Idade do Bronze do noroeste Português. Alguns dados para uma reflexão

Ana M. S. Bettencourt / Sara Luz / Nuno Oliveira / Pedro P. Simões / Maria Isabel C. Alves / Emílio Abad-Vidal

1001 A estátua-menir do Pedrão ou de São Bartolomeu do Mar (Esposende, noroeste de Portugal) no contexto arqueológico da fachada costeira de entre os rios Neiva e Cávado Ana M. S. Bettencourt / Manuel Santos-Estévez / Pedro Pimenta Simões / Luís Gonçalves

1015 O Castro do Muro (Vandoma/Baltar, Paredes) - notas para uma biografia de ocupação da Idade do Bronze à Idade Média

Maria Antónia D. Silva / Ana M. S. Bettencourt / António Manuel S. P. Silva / Natália Félix

1031 Do Bronze Final à Idade Média - continuidades e hiatos na ocupação de Povoados em Oliveira de Azeméis João Tiago Tavares / Adriaan de Man

1041 As faunas do final da Idade do Bronze no Sul de Portugal: leituras desde o Outeiro do Circo (Beja)

Nelson J. Almeida / Íris Dias / Cleia Detry / Eduardo Porfírio / Miguel Serra

1055 A Espada do Monte das Oliveiras (Serpa) - uma arma do Bronze Pleno do Sudoeste Rui M. G. Monge Soares / Pedro Valério / Mariana Nabais / António M. Monge Soares

1065 São Julião da Branca (Albergaria-a-Velha) - Investigação e valorização de um povoado do Bronze Final

António Manuel S. P. Silva / Paulo A. P. Lemos / Sara Almeida e Silva / Edite Martins de Sá

1083 Do castro de S. João ao Mosteiro de Santa Clara: notícia de uma intervenção arqueológica, em Vila do Conde Rui Pinheiro 
1095 O castro de Ovil (Espinho), um quarto de século de investigação - resultados e questões em aberto

Jorge Fernando Salvador / António Manuel S. P. Silva

1111 O Castro de Salreu (Estarreja), um povoado proto-histórico no litoral do Entre Douro e Vouga

Sara Almeida e Silva / António Manuel S. P. Silva / Paulo A. P. Lemos / Edite Martins de Sá

1127 Castro de Nossa Senhora das Necessidades (Sernancelhe): uma primeira análise artefactual Telma Susana O. Ribeiro

${ }_{1141}$ A cividade de Bagunte. O estado atual da investigação Pedro Brochado de Almeida

1153 Zoomorfos na cerâmica da Idade do Ferro no NW Peninsular: inventário, cronologias e significado Nuno Oliveira / Cristina Seoane

1163 Vasos gregos em Portugal: diferentes maneiras de contar a história do intercâmbio cultural na Idade do Ferro

Daniela Ferreira

1175 Os exotica da necrópole da Idade do Ferro do Olival do Senhor dos Mártires (Alcácer do Sal) no seu contexto regional

Francisco B. Gomes

\section{Antiguidade Clássica e Tardia}

1191 O uso de madeira como combustível no sítio da Quinta de Crestelos (Baixo Sabor): da Idade do Ferro à Romanização Filipe Vaz / João Tereso / Sérgio Simões Pereira / José Sastre / Javier Larrazabal Galarza / Susana Cosme / José António Pereira / Israel Espi

1207 Cultivos de Época Romana no Baixo Sabor: continuidade em tempos de mudança? João Pedro Tereso / Sérgio Simões Pereira / Filipe Santos / Luís Seabra / Filipe Vaz

1221 A casa romana na Hispânia: aplicação dos modelos itálicos nas províncias ibéricas Fernanda Magalhães / Diego Machado / Manuela Martins

1235 As pinturas murais romanas da Rua General Sousa Machado, n. ${ }^{5}$ 1, Chaves José Carvalho

1243 Trás do Castelo (Vale de Mir, Pegarinhos, Alijó) - Uma exploração agrícola romana do Douro

Tony Silvino / Pedro Pereira

1255 A sequência de ocupação no quadrante sudeste de Bracara Augusta: as transformações de uma unidade doméstica Lara Fernandes / Manuela Martins

1263 Os Mosaicos com decoração geométrica e geométrico-vegetalista dos sítios arqueológicos da área do Conuentus Bracaraugustanus. Novas abordagens quanto à conservação, restauro, decoração e datação Maria de Fátima Abraços / Licínia Wrench

1277 “Casa Romana” do Castro de São Domingos (Cristelos, Lousada): Escavação, Estudo e Musealização Paulo André de P. Lemos

1291 A arqueobotânica no Castro de Guifões (Matosinhos, Noroeste de Portugal): O primeiro estudo carpológico

Luís Seabra / Andreia Arezes / Catarina Magalhães / José Varela / João Pedro Tereso 
1305 Um Horreum Augustano na Foz do Douro (Monte do Castelo de Gaia, Vila Nova de Gaia) Rui Ramos

1311 Ponderais romanos na Lusitânia: padrões, formas, materiais e contextos de utilização Diego Barrios Rodríguez

1323 Um almofariz centro-itálico na foz do Mondego

Marco Penajoia

1335 Estruturas romanas de Carnide - Lisboa Luísa Batalha / Mário Monteiro / Guilherme Cardoso

1347 O contexto funerário do sector da "necrópole NO" da Rua das Portas de S. Antão (Lisboa): o espaço, os artefactos, os indivíduos e a sua interconectividade na interpretação do passado Sílvia Loja, José Carlos Quaresma, Nelson Cabaço, Marina Lourenço, Sílvia Casimiro, Rodrigo Banha da Silva, Francisca Alves-Cardoso

${ }_{1361}$ Povoamento em época Romana na Amadora - resultados de um projeto pluridisciplinar Gisela Encarnação / Vanessa Dias

1371 A Arquitectura Residencial em Mirobriga (Santiago do Cacém): contributo a partir de um estudo de caso Filipe Sousa / Catarina Felício

${ }_{1385}$ O fim do ciclo. Saneamento e gestão de resíduos nos edifícios termais de Mirobriga (Santiago do Cacém)

Catarina Felício / Filipe Sousa

1399 Balsa, Topografia e Urbanismo de uma Cidade Portuária Vítor Silva Dias / João Pedro Bernardes / Celso Candeias / Cristina Tété Garcia

1413 No Largo das Mouras Velhas em Faro (2017): novas evidências da necrópole norte de Ossonoba e da sua ocupação medieval Ricardo Costeira da Silva / Paulo Botelho / Fernando Santos / Liliana Nunes

1429 Instrumentos de pesca recuperados numa fábrica de salga em Ossonoba (Faro) Inês Rasteiro / Ricardo Costeira da Silva / Paulo Botelho

1439 A Necrópole Romana do Eirô, Duas Igrejas (Penafiel): intervenção arqueológica de 2016 Laura Sousa / Teresa Soeiro

1457 Ritual, descarte ou afetividade? A presença de Canis lupus familiaris na Necrópole Noroeste de Olisipo (Lisboa)

Beatriz Calapez Santos / Sofia Simões Pereira / Rodrigo Banha da Silva / Sílvia Casimiro / Cleia Detry / Francisca Alves Cardoso

1467 Dinâmicas económicas em Bracara na Antiguidade Tardia Diego Machado / Manuela Martins / Fernanda Magalhães / Natália Botica

1479 Cerâmicas e Vidros da Antiguidade Tardia do Edifício sob a Igreja do Bom Jesus (Vila Nova de Gaia) Joaquim Filipe Ramos

1493 Novos contributos para a topografia histórica de Mértola no período romano e na Antiguidade Tardia Virgílio Lopes

\section{8. Época Medieval}

1511 Cerâmicas islâmicas no Garb setentrional "português": algumas evidências e incógnitas Constança dos Santos / Helena Catarino / Susana Gómez / Maria José Gonçalves / Isabel Inácio / Gonçalo Lopes / Jacinta Bugalhão / Sandra Cavaco / Jaquelina Covaneiro / Isabel Cristina Fernandes / Ana Sofia Gomes 
1525 Contributo para o conhecimento da cosmética islâmica, em Silves, durante a Idade Média Rosa Varela Gomes

1537 Yábura e o seu território - uma análise histórico-arqueológica de Évora entre os séculos VIII-XII José Rui Santos

1547 A encosta sul do Castelo de Palmela - resultados preliminares da escavação arqueológica Luís Filipe Pereira / Michelle Teixeira Santos

1559 A igreja de São Lourenço (Mouraria, Lisboa): um conjunto de silos e de cerâmica medieval islâmica

Andreia Filipa Moreira Rodrigues

1571 O registo material de movimentações populacionais no Médio Tejo, durante os séculos XII-XIII. Dois casos de "sunken featured buildings", nos concelhos de Cartaxo e Torres Novas Marco Liberato / Helena Santos / Nuno Santos

1585 O nordeste transmontano nos alvores da Idade média. Notas para reflexão Ana Maria da Costa Oliveira

1601 Sepulturas escavadas na rocha do Norte de Portugal e do Vale do Douro: primeiros resultados do Projecto SER-NPVD

Mário Jorge Barroca / César Guedes / Andreia Arezes / Ana Maria Oliveira

1619 "Portucalem Castrum Novum" entre o Mediterrâneo e o Atlântico: o estudo dos materiais cerâmicos alto-medievais do arqueossítio da rua de D. Hugo, nํ. 5 (Porto) João Luís Veloso

1627 A Alta Idade Média na fronteira de Lafões: notas preliminares sobre a Arqueologia no Concelho de Vouzela

Manuel Luís Real / Catarina Tente

1641 Um conjunto cerâmico medieval fora de portas: um breve testemunho aveirense Susana Temudo

${ }_{1651}$ Os Lóios do Porto: uma perspetiva integrada no panorama funerário da Baixa Idade Média à Época Moderna em meios urbanos em Portugal

Ana Lema Seabra

1659 O Caminho Português Interior de Santiago como eixo viário na Idade Média Pedro Azevedo

1665 Morfologia Urbana: Um exercício em torno do Castelo de Ourém André Donas-Botto / Jaqueline Pereira

1677 Intervenção arqueológica na Rua Marquês de Pombal/Largo do Espírito Santo (Bucelas, Loures)

Florbela Estêvão / Nathalie Antunes-Ferreira / Dário Ramos Neves / Inês Lisboa

1691 O Cemitério Medieval do Poço do Borratém e a espacialidade funerária na cidade de Lisboa Inês Belém / Vanessa Filipe / Vasco Noronha Vieira / Sónia Ferro / Rodrigo Banha da Silva

1705 Um Espaço Funerário Conventual do séc. XV em Lisboa: o caso do Convento de São Domingos da Cidade Sérgio Pedroso / Sílvia Casimiro / Rodrigo Banha da Silva / Francisca Alves Cardoso

\section{9. Época Moderna e Contemporânea}

1721 Arqueologia Moderna em Portugal: algumas reflexões críticas em torno da quantificação de conjuntos cerâmicos e suas inferências históricas e antropológicas Rodrigo Banha da Silva / André Bargão / Sara da Cruz Ferreira

1733 Faianças de dois contextos entre os finais do século XVI e XVIII do Palácio dos Condes de Penafiel, Lisboa

Martim Lopes / Tomás Mesquita 
1747 Um perfil de consumo do século XVIII na foz do Tejo: O caso do Mercado da Ribeira, Lisboa Sara da Cruz Ferreira / Rodrigo Banha da Silva / André Bargão

1761 Os Cachimbos dos Séculos XVII e XVIII do Palácio Mesquitela e Convento dos Inglesinhos (Lisboa)

Inês Simão / Marina Pinto / João Pimenta / Sara da Cruz Ferreira / André Bargão / Rodrigo Banha da Silva

1775 "Tomar os fumos da erua que chamão em Portugal erua sancta». Estudo de Cachimbos provenientes da Rua do Terreiro do Trigo, Lisboa

Miguel Martins de Sousa / José Pedro Henriques / Vanessa Galiza Filipe

1787 Cachimbos de Barro Caulínitico da Sé da Cidade Velha (República de Cabo Verde)

Rodrigo Banha da Silva / João Pimenta / Clementino Amaro

1801 Algumas considerações sobre espólio não cerâmico recuperado no Largo de Jesus (Lisboa) Carlos Boavida

1815 Adereços de vidro, dos séculos XVI-XVIII, procedentes do antigo Convento de Santana de Lisboa (anéis, braceletes e contas)

Joana Gonçalves / Rosa Varela Gomes / Mário Varela Gomes

1837 Da ostentação, luxo e poder à simplicidade do uso quotidiano: arqueologia e simbologia de joias e adornos da Idade Moderna Portuguesa Jéssica Iglésias

1849 Os amuletos em Portugal - dos objetos às superstições: o coral vermelho Alexandra Vieira

1865 Cerâmicas de Vila Franca de Xira nos séculos XV e XVI Eva Pires

1879 «Não passa por teu o que me pertence». Marcas de individualização associadas a faianças do Convento de Nossa Senhora de Aracoeli, Alcácer do Sal Catarina Parreira / Íris Fragoso / Miguel Martins de Sousa

1891 Cerâmica de Leiria: alguns focos de produção

Jaqueline Pereira / André Donas-Botto

1901 Os Fornos na Rua da Biquinha, em Óbidos Hugo Silva / Filipe Oliveira

1909 A casa de Pêro Fernandes, contador dos contos de D. Manuel I: o sítio arqueológico da Silha do Alferes, Seixal (século XVI) Mariana Nunes Ferreira

1921 O Alto da Vigia (Sintra) e a vigilância e defesa da costa Alexandre Gonçalves / Sandra Santos

1937 O contexto da torre sineira da Igreja de Santa Maria de Loures Paulo Calaveira / Martim Lopes

1949 A Necrópole do Hospital Militar do Castelo de São Jorge e as práticas funerárias na Lisboa de Época Moderna Susana Henriques / Liliana Matias de Carvalho / Ana Amarante / Sofia N. Wasterlain

1963 SAND - Sarilhos Grandes Entre dois Mundos: o adro da Igreja e a Paleobiologia dos ossos humanos recuperados

Paula Alves Pereira / Roger Lee Jesus / Bruno M. Magalhães

1975 Expansão urbana da vila de Cascais no século XVII e XVIII: a intervenção arqueológica na Rua da Vitória no 15 a 17

Tiago Pereira / Vanessa Filipe

1987 Novos dados para o conhecimento do Urbanismo de Faro em época Moderna Ana Rosa 
1995 Um exemplo de Arqueologia Urbana em Alcoutim: o Antigo Edifício dos CTT Marco Fernandes / Marta Dias / Alexandra Gradim / Virgílio Lopes / Susana Gómez Martínez

2007 Palácio dos Ferrazes (Rua das Flores/Rua da Vitória, Porto): a cocheira de Domingos Oliveira Maia

Francisco Raimundo

2021 As muitas vidas de um edifício urbano: História, Arqueologia e Antropologia no antigo Recreatório Paroquial de Penafiel Helena Bernardo / Jorge Sampaio / Marta Borges

2035 O convento de Nossa Senhora da Esperança de Ponta Delgada: o contributo da arqueologia para o conhecimento de um monumento identitário João Gonçalves Araújo / N’Zinga Oliveira

2047 Arqueologia na ilha do Corvo... em busca da capela de Nossa Senhora do Rosário Tânia Manuel Casimiro / José Luís Neto / Luís Borges / Pedro Parreira

2059 Perdidos à vista da Costa. Trabalhos arqueológicos subaquáticos na Barra do Tejo Jorge Freire / José Bettencourt / Augusto Salgado

2071 Arqueologia marítima em Cabo Verde: enquadramento e primeiros resultados do projecto CONCHA

José Bettencourt / Adilson Dias / Carlos Lima / Christelle Chouzenoux / Cristóvão Fonseca / Dúnia Pereira / Gonçalo Lopes / Inês Coelho / Jaylson Monteiro / José Lima / Maria Eugénia Alves / Patrícia Carvalho / Tiago Silva

2085 Trabalhos arqueológicos na Cidade Velha (Ribeira Grande de Santiago, Cabo Verde): reflexões sobre um projecto de investigação e divulgação patrimonial André Teixeira / Jaylson Monteiro / Mariana Mateus / Nireide Tavares / Cristovão Fonseca / Gonçalo C. Lopes / Joana Bento Torres / Dúnia Pereira / André Bargão / Aurélie Mayer / Bruno Zélie / Carlos Lima / Christelle Chouzenoux / Inês Henriques / Inês Pinto Coelho / José Lima / Patrícia Carvalho / Tiago Silva

2103 A antiga fortificação de Quelba / Khor Kalba (E.A.U.). Resultados de quatro campanhas de escavações, problemáticas e perspectivas futuras Rui Carita / Rosa Varela Gomes / Mário Varela Gomes / Kamyar Kamyad

2123 Colónias para homens novos: arqueologia da colonização agrária fascista no noroeste ibérico Xurxo Ayán Vila / José Mạ . Señorán Martín 


\title{
GRAVURAS RUPESTRES DE BARQUIFORMES NO MONTE DE S. ROMÃO, GUIMARÃES, NOROESTE DE PORTUGAL
}

\author{
Daniela Cardoso ${ }^{1}$
}

RESUMO

O Monte de S. Romão localiza-se na margem direita do rio Ave, no concelho de Guimarães, no Noroeste de Portugal.

A primeira referência de arte rupestre no Monte de S. Romão deve-se a Martins Sarmento que no século XIX relatou a existência de gravuras (Sarmento, F., 1901; 1904; 1905; 1933). Investigações recentes concentraram-se num conjunto substancial de arte rupestre que está disperso por grande parte do local (Cardoso, D., 2011, 2015, Nash, G., Cardoso, D., Ferreira, E., 2013).

O objetivo deste trabalho é o de apresentar três suportes gravados do Monte de S. Romão, sendo que dois deles, em nossa opinião, foram publicados em posição invertida. Com esta nova abordagem, colocamos a hipótese de que estes representam barquiformes pré-históricos. Apesar de preliminar, este trabalho pretendeu contribuir para aumentar os conhecimentos sobre a arte rupestre pós-paleolítica de ar livre do Noroeste português e em especial do enigmático Monte de S. Romão (onde se localiza a Citânia de Briteiros), bem como promover novas questões sobre o local.

Palavras-chave: Arte Rupestre, Barquiformes, Monte de S. Romão, Noroeste de Portugal, Valorização Patrimonial.

\begin{abstract}
Monte de S. Romão is located on the right bank of the river Ave, in the municipality of Guimarães, in the northwest of Portugal. The first reference of rock art in Monte de S. Romão is due to Martins Sarmento who in the 19th century reported the existence of engravings (Sarmento, F., 1901; 1904; 1905; 1933). Recent investigations have focused on the substantial set of rock art that is dispersed over a large part of the site (Cardoso, D., 2011, 2015, Nash, G., Cardoso, D., Ferreira, E., 2013).

The purpose of this work is to present three outcrops recorded from Monte de São Romão, from which, in our opinion, two of them were published in an inverted position. With this new approach, we hypothesize that they represent prehistoric boats. Despite being preliminary, this work intended to contribute to increase knowledge about post-paleolithic rock art in the Portuguese Northwest and especially the enigmatic Monte de S. Romão (where is located Citânia de Briteiros), as well as to promote new questions about the occupation of this place and adjacent territory.

Keywords: Rock Art, Boats, Mount of S. Romão, Northwest of Portugal, Valorization of heritage.
\end{abstract}

\section{INTRODUÇÃO}

O objetivo do presente trabalho é o de dar notícia da existência de três representações de embarcações do
Monte de S. Romão. Uma delas está gravada num bloco granítico atualmente exposto no Museu Arqueológico da Sociedade Martins Sarmento (SMS) e faria parte de um afloramento de maiores dimen-

1. Sociedade Martins Sarmento, Guimarães, Portugal; Centro de Geociências da Universidade de Coimbra; Laboratório de Paisagens, Património e Território - Lab2pt; daniela.cardoso@msarmento.org 
sões que existiu junto ao balneário sul da Citânia de Briteiros (Cardozo, M., 1932, p. 22), ou seja, a meia vertente , a nordeste do Monte de S. Romão. A outra representação encontra-se igualmente localizada a meia vertente do Monte de S. Romão, no meio de um caminho antigo que fazia ligação entre Donim e a Citânia de Briteiros e foi detetada em 2011 no âmbito do projeto de doutoramento intitulado "A Arte Atlântica do Monte de S. Romão (Guimarães) no Contexto da Arte Rupestre Pós-paleolítica da Bacia do Ave-Noroeste Português", e de um projeto mais vasto designado "Espaços naturais, arquitecturas, arte rupestre e deposições na pré-história recente da fachada ocidental do centro norte português: das ações aos significados - Enardas”. Nessa altura, o afloramento gravado Bouça da Miséria foi estudado, realizando-se o seu levantamento topográfico, fotográfico e gráfico (Cardoso D., 2015, pp. 59-6o).

A última representação, que ainda não foi relocalizada encontrar-se-á na área adjacente ao cemitério da Citânia de Briteiros, próxima do topo do Monte de S. Romão. Para esta pedra gravada dispomos apenas dos dados de Martins Sarmento (Sarmento, F., 1905, p. 23).

As figuras de embarcações gravadas eram consideradas uma temática rara no Noroeste Peninsular, mas trabalhos recentes de alguns autores (Santos, A., 2014; Bettencourt, A., 2017) vieram clarificar esse tipo de representações nesta área geográfica. Nesse sentido, o Monte de S. Romão apresenta novos dados sobre este tipo de motivos e introduz novas interpretações, merecendo por esse motivo a continuidade do seu estudo e valorização patrimonial.

Neste trabalho coloca-se a seguinte questão: que tipo de narrativa está por detrás destas representações?

\section{CARATERIZAÇÃO ADMINISTRATIVA, FÍSICA E AMBIENTAL}

O Monte de S. Romão (336 m) localiza-se no Noroeste de Portugal, no distrito de Braga, concelho de Guimarães, na freguesia de S. Salvador de Briteiros, na margem direita do rio Ave.

A área geográfica da bacia hidrográfica do rio Ave situa-se na região do Baixo Minho. Encontra-se rodeada pela costa Atlântica, a oeste; pela bacia do Cávado e o Parque Nacional da Peneda-Gerês, a norte; pela região Transmontana, a este e pelas bacias do Leça e Douro, a sul. O rio Ave, que percorre cerca de $100 \mathrm{~km}$, tem a sua nascente a mais de $1050 \mathrm{~m}$ de alti- tude, na Serra da Cabreira, e vai desaguar no Oceano Atlântico entre Vila do Conde, a norte, e Azurara, a sul (Figura 1).

O Monte de S. Romão corresponde a um esporão, sobranceiro ao Ave, que faz parte de um maciço orográfico que separa os vales do Ave e do Cávado, destacando-se da serra da Cabreira. "Esse esporão perfeitamente recortado na direção N-S, desce desde o Monte Alto (cota 417), em declive pouco acentuado, até ao local da Citânia, de cota 336" (Cardozo, M., 1990, p. 9) (Figura 2).

Neste monte existe uma grande abundância de nascentes, derivadas do substrato granítico, uma rocha favorável à formação de lençóis de água subterrâneos (Lemos \& Cruz, 2011, p. 38). Vestígios dessas nascentes, são um reservatório de água e as condutas que foram construídas na Citânia de Briteiros. Dos cursos de água que o circundam são de destacar o ribeiro que nasce na Sobreposta, freguesia vizinha de S. Salvador de Briteiros, com o nome de Agrela, também conhecido por Briteiros ou Febras e que desagua, por fim, com o nome de Rabelo (?), na margem direita do Ave, um pouco a montante das Caldas das Taipas. (Cardozo, M., 1990, pp. 9-10).

De acordo com informações recolhidas no mapa geológico da bacia hidrográfica do rio Ave (Costa, F., 2007, p. 139), o tipo de rocha predominante no Monte de S. Romão é o denominado "granito de Briteiros". "Desta variedade de granito ocorrem várias manchas, sendo a mais extensa a que ocorre no centro da carta e que se estende da Serra do Carvalho à povoação de Briteiros”. A composição do granito de Briteiros corresponde a um leucogranito moscovítico-biotítico de grão fino. Tem ainda na sua constituição “moscovite por vezes em grande concentração, turmalina, frequentes encraves metassedimentares e pequenos encraves micáceos que contêm silimanite” (Ferreira \& alii 200o, p. 29) (Figura 3).

\section{CONSIDERAÇÕES TEÓRICAS E METODOLÓGICOS}

Em termos metodológicos optou-se por uma posição eclética baseada numa postura interpretativa que tem como base as premissas de que todo o conhecimento é subjetivo e de que as ações são tanto reflexo do pensamento simbólico das comunidades, como agentes no seu quotidiano, numa perspetiva próxima de Gell (1998) e de Ingold (2000). 
No tocante à praxis, o trabalho foi estruturado em momentos diferentes (entre 2011 e 2019), tendo em conta etapas distintas: trabalho preparatório de gabinete, trabalho de campo, trabalho de laboratório e trabalho avançado de gabinete.

A primeira etapa consistiu na pesquisa bibliográfica sobre a história das investigações e contexto arqueológico. Foi também consultada cartografia, nomeadamente cartas militares, cartas geológicas, mapas hidrográficos que nos forneceram informações sobre o território em estudo, muito especialmente sobre a geologia e a hidrografia, o que foi crucial para a compreensão do contexto envolvente aos lugares gravados.

Na segunda etapa, foram contemplados o trabalho de prospeção arqueológica ou relocalização, limpeza mecânica não abrasiva e levantamento fotográfico e gráfico do afloramento gravado da Bouça da Miséria (Figuras 4a e b) e do bloco musealizado exposto na SMS, ambos do Monte de S. Romão.

Relativamente à relocalização de uma gravura mencionada por Martins Sarmento no séc. XIX, e que neste trabalho se coloca a hipótese de se tratar de um barquiforme, dada a densidade de líquenes existente nos suportes pétreos da Citânia e as informações genéricas de Martins Sarmento, até ao momento ainda não foi possível relocalizá-la.

Numa terceira etapa, procedeu-se à digitalização dos plásticos polivinílicos utlizados na fase de levantamento gráfico e realizou-se o trabalho de edição e tratamento de imagem através do programa Photoshop. Para o caso especifico do bloco granítico musealizado, exposto no jardim anexo ao claustro de S. Domingos, na Sociedade Martins Sarmento, foi ainda ensaiado um modelo $3 \mathrm{D}$ baseado em fotografias capturadas pela aplicação DJI Phantom e foi gerado usando 3 DF Zephyr v. 4009, software de fotogrametria. (Figura 4c). Este processo foi dificultado pela existência de uma grande concentração de líquenes no suporte granítico pelo que numa fase posterior tornou-se necessário proceder-se a uma limpeza mecânica.

\section{BREVE DESCRIÇÃO DOS SUPORTES GRAVADOS NO MONTE DE S. ROMÃO}

\subsection{Afloramento gravado da Bouça da Miséria}

Localiza-se na freguesia de Briteiros (S. Salvador), a meia vertente, a nordeste no Monte de S. Romão, ainda, dentro da zona especial de proteção da Citânia de Briteiros e próximo de linhas de água e de nascentes, sendo de assinalar o rio Febras, na margem direita do Ave. O afloramento gravado encontra-se localizado numa zona de fácil acesso e de onde é possível usufruir de uma ampla visibilidade destacando-se no horizonte, para nordeste, a Serra do Gerês, as Serras da Cabreira, das Alturas e do Barroso e a sudeste o Monte da Penha.

O afloramento gravado da Bouça da Miséria, detetado em 2006 e posteriormente estudado em 2011, no âmbito do projeto de investigação da arte rupestre do Monte de S. Romão, apresenta um motivo peculiar de um barquiforme, entre outros (Nash, G., Cardoso, D., Ferreira, E., 2013; Cardoso, D., 2015, pp. 173-175). Em 2011 foi realizado o levantamento fotográfico diurno e noturno com máquina digital (Figura 5a), levantamento topográfico e decalque direto (Figura $5 \mathrm{~b}$ ). Durante o processo de registo deu-se especial importância a todos os detalhes morfológicos e técnicos dos motivos gravados.

A Bouça da Miséria corresponde a uma laje granítica bastante erodida, de grandes dimensões, medindo cerca de 9,75 $\mathrm{m}$ por 5,31 $\mathrm{m}$ com uma diagonal de 9,35 m., embora parte dela ainda esteja soterrada. Tem uma superfície bastante regular, rasante ao solo, de cor acinzentada, formato semi-retangular. Apresenta um reportório iconográfico incomum, mais precisamente um motivo barquiforme com o,59m por o,30 m., um antropomorfo sexuado medindo $33 \mathrm{~cm}$ por $20 \mathrm{~cm}$, dois círculos concêntricos com e sem covinha central medindo entre 0,26 e 0,27 m de diâmetro e diversas covinhas. Todos os motivos foram realizados por intermédio da técnica de percussão, e em alguns casos seguidos de abrasão (Cardoso, D., 2015, p. 173).

\subsection{Bloco gravado musealizado}

O bloco granítico atualmente musealizado, foi descrito e desenhado por Martins Sarmento no séc. XIX (Sarmento, F., 1904, p. 61). Em 26 de junho de 1876, escreveu Martins Sarmento nas suas notas sobre o achado: "O signal que lhe corresponde do lado da Cavada (quasi a sul) e que fica na linha que se tirasse da capela para a poça da Cavada, n'uma lage que fica à beira do caminho (direita subindo) por onde foi a "pedra formosa", é muito diferente. Espiral (...) O outro sinal é (...) Ambos eles estão gravados no lado noroeste da lage. Este segundo sinal tem alguma cousa com os cinco dedos? Estes signaes nas lages devem ser mais.” Mais tarde, Mário Cardoso 
(1932) menciona novamente as gravuras rupestres num texto publicado na Revista de Guimarães: (...) “E' oportuno dizer que também junto ao novo monumento citaniense se encontram numerosos penedos com insculturas, algumas bastante originais, como a que reproduzimos na fig. 15, já notada por M. Sarmento (8). Infelizmente muitos desses penedos desapareceram, soterrados ou partidos, na ocasião da abertura da nova estrada, tendo sido sacrificados às necessidades do traçado. Daquele, cuja gravura reproduzimos, salvou-se apenas uma parte, não tendo escapado ao camartelo a espiral que Sarmento reproduziu no mesmo agrupamento." (...) (Cardozo, M., 1932, p. 22). Nessa mesma publicação, o investigador produz um novo desenho, mais detalhado do que o anterior, mas sem a representação da espiral.

De acordo com as informações de Martins Sarmento e de Mário Cardoso, depreendemos que o bloco gravado faria parte de um afloramento de maiores dimensões que se encontrava próximo do balneário sul na Citânia de Briteiros. Aquando da construção da estrada EN 309, em 1930, a Sociedade Martins Sarmento teve uma intervenção no sentido de salvaguardar este emblemático monumento bem como de outros vestígios que se encontravam nas imediações do mesmo, como é o caso do bloco gravado em análise (Cardoso, M., 2015, pp. 180-181).

Este fragmento foi transferido para o Museu arqueológico da SMS em 1934 e aí se encontra desde essa data (Figura 6a). Mede $113 \mathrm{~cm}$ por $87 \mathrm{~cm}$, apresenta-se erodido e apresentava uma grande concentração de líquenes. Tem um reportório iconográfico incomum, nomeadamente a gravura de um barquiforme, medindo $25 \mathrm{~cm}$ por $26 \mathrm{~cm}$, um motivo indeterminado com $18 \mathrm{~cm}$ por $23 \mathrm{~cm}$ e vestígios de um outro, inconclusivo, uma vez que se encontra extremamente erodido.

Em 2019 foi realizado o decalque direto do bloco gravado (Figura 6b) e um modelo em $3 \mathrm{D}$ com vista a obter uma melhor compreensão dos motivos ali gravados e complementar o estudo do mesmo.

Todos os motivos foram realizados por intermédio da técnica de percussão, seguida, aparentemente, de abrasão.

\subsection{Pedra gravada referida por Sarmento}

De acordo com a descrição e registo gráfico (Sarmento, F., 1905a, p. 23) e fotografias pertencentes aos álbuns fotográficos de Martins Sarmento, obteve-se a informação de que o motivo se encontrava na estrutura de uma parede, localizada na proximidade do cemitério da Citânia de Briteiros (Figuras. 7a, b e c). Até à data ainda não nos foi possível relocalizá-la, tornando-se, portanto interessante analisar o texto referente à notícia da descoberta desta pedra gravada: (...) "O desaterro tem continuado no taboleiro inferior ao outro contiguo ao cemiterio. Passa adiante da casa onde o Luciano Cordeiro encontrou a figura d'um animal com cornos, cuja figura, aliás sem cornos, é: (...)” (Sarmento, F., 1905a, p. 23).

Não existindo mais dados sobre a pedra gravada e contrariando a indicação de que poderia tratar-se da gravação da figuração de um animal, entende-se agora que a figura aí representada poderá corresponder a um hipotético barquiforme, com base em semelhanças estilísticas de outros motivos análogos e estudos realizados por vários investigadores sobre a temática das embarcações.

Apesar de não dispormos de dados mais detalhados sobre a gravura do barquiforme, parece-nos que os motivos foram realizados por intermédio da técnica de percussão.

\section{DISCUSSÃO DE DADOS: PROPOSTA CRONOLÓGICA E INTERPRETAÇÕES}

A paisagem da bacia do Ave, repleta de rios e inúmeras linhas de água que alimentam a riqueza da biodiversidade e da paisagem, ditou a ocupação pelo Homem, durante milhares de anos, de todo um vasto território. As barcas e barcos, nas suas diferentes tipologias, terão sido um dos meios privilegiados de comunicação e transporte fluvial desde os cumes dos montes até ao atlântico.

No monte de S. Romão obtém-se um controlo visual para o vale do Ave, sendo possível observar desde o seu topo, na linha do horizonte, a zona litoral, onde desagua o rio Ave. De acordo com estudiosos da antiguidade clássica, como Estrabão, as águas do rio Ave banhavam as faldas do monte de S. Romão, o que fortalece a tese de que os habitantes do monte teriam contactos estabelecidos entre este local e a zona costeira atlântica.

Poderão formular-se perguntas tais como: será que os povos que por ali circulavam representavam o que viam? Terão sido estes povos testemunhas da memória destes contactos?

Considerando a possibilidade do controlo visual da costa a partir do interior pode pois hipotetizar-se que as embarcações fariam parte deste cenário e que 
a sua representação ocorreu no Monte de S. Romão. Atualmente torna-se difícil equacionar todas estas hipóteses dado que o rio Ave designado pelos romanos de Avus, é presentemente apenas navegável numa curta extensão de $2 \mathrm{Km}$, junto à foz, uma vez que sua possível navegabilidade para montante foi interrompida pela construção de diversos açudes e barragens (Cardoso, 2015 , p. 23). Terá então que ser feito um exercício de mudança de olhar ou de diferentes formas de olhar.

Graças aos arquivos fotográficos de coleções privadas e públicas, do final do século XIX e primeiro quartel do século XX, conhecemos a riqueza e a variedade dos barcos e barcas de carga e de passagem nos rios do Noroeste peninsular. A título de exemplo, e através do espólio fotográfico pertencente à fototeca da SMS, é possível observar-se no início do séc. XX, um troço do rio Ave e suas embarcações (Figura 8), herdeiras de alguma da materialidade dos barcos e barcas produzidas pelas comunidades humanas durante milhares de anos.

Interpretar estes lugares e os motivos ali gravados é uma tarefa difícil, tanto mais que o Monte de S. Romão, no âmbito da sua ampla diacronia, poderá ter sido palco de vários sentidos.

É a partir destas e de outras possíveis considerações que podemos realizar um exercício de reflexão a partir das gravuras de barquiformes do Monte de S. Romão.

Relativamente ao bloco gravado, atualmente musealizado, tal como foi atrás mencionado, foi realizado em 1876 um primeiro esboço muito rudimentar por Martins Sarmento (Figura 9a) (Sarmento, F., 1904, p. 61). Já em 1878, o mesmo autor publica o seu segundo álbum de fotografias e aí coloca a imagem gravada numa posição que em nossa opinião será a mais correta, (Figura 9b) pois foi ele a primeira pessoa a visualizá-la no seu contexto original. Posteriormente, foi realizado um segundo registo gráfico mais detalhado, por Mário Cardozo (Figura 9c) (1932, p. 22) mas publicado em posição invertida, sendo de deduzir que aquando do transporte deste fragmento para o Museu da SMS se tenha optado por colocá-lo nessa posição, não correspondendo à original in situ. Desse modo, os motivos nele gravados poderão ter uma leitura diferente. Se invertermos a pedra, em relação à posição em que se encontra na atualidade, um dos motivos parece representar um barquiforme com a proa alteada. Esta experiência foi realizada com o desenho de Mário Cardozo (Figura 9d).
Com esta nova abordagem, colocamos a hipótese de que o motivo gravado representa um barquiforme pré-histórico, gravado através da técnica de percussão, com a representação de uma proa e apresentando um casco ligeiramente curvo. No mesmo bloco encontram-se ainda gravados dois motivos indeterminados, um deles, por sinal, bastante curioso e bastante bem conservado. Porém, não podemos tecer nenhuma consideração, já que até ao presente, ainda não foi encontrado nenhum motivo análogo.

Apesar da representação de barquiformes se tratar de uma temática pouco comum na Península Ibérica, ainda assim, recentemente, têm aparecido principalmente no norte da zona litoral portuguesa, novas representações de embarcações.

No Minho, no contexto da Arte Atlântica, foram encontrados vários tipos de barquiformes na Laje da Churra, em Carreço, Viana do Castelo (Santos, A., 2013), (Figura 10a) Eira do Louvado, Viana do Castelo e Santo Adrião 2, (Figura 1ob) no concelho de Caminha (Bettencourt A., 2017; Santos Estévez \& Bettencourt, 2017). Já na Galiza são conhecidos alguns exemplares, como os barquiformes de Oia, em Pedornes (Santa María de Oia) (Alonso Romero, 1974), barquiformes de Borna, (Figura 10c) em Meira, Galiza (García Alén \& Peña Santos, 1980) e barquiforme de Auga dos Cebros (Costas Goberna \& Peña Santos, 2006, p. 289).

Perante a falta de paralelos no Noroeste Peninsular, para o barquiforme localizado no bloco musealizado do Museu Arqueológico da SMS, foram, no entanto, encontradas semelhanças estilísticas nas embarcações do Norte de Tanumm, Bohuslãn, Suécia (Figura 1od) (Goldhahn, J.; Ling, J., 2013, p. 276). De acordo com Bettencourt (Bettencourt, A., 2013a, 2013b; Santos, A., 2014) este tipo de representações surge desde a Idade do Bronze, momento, a partir do qual se intensificam as navegações na fachada atlântica. É de referir a presença de contactos entre a Ibéria e a Escandinávia, durante a Idade do Bronze, nomeadamente durante o Bronze Final. Esta hipótese tem vindo a ser defendida através de dados arqueológicos e arqueométricos por Ling Stos-Gale (2015, p. 215-217).

Já no que se refere ao barquiforme da Bouça da Miséria, (Figura 1oe) apesar do afloramento rochoso ter grandes dimensões, o reduzido número de motivos ali gravados pode ter tido um propósito diferente por parte do(s) seus autor(es) uma vez que a sua iconografia é bastante distinta relativamente a todos 
os outros sítios do monte. Apesar do afloramento granítico rasante ao solo apresentar uma aparência muito regular, os motivos encontram-se dispersos ao longo de toda a sua superfície, ocorrendo duas figurações circulares (dois círculos concêntricos) covinhas, o motivo do barquiforme e um possível antropomorfo sexuado. Entre todos estes motivos não parece existir uma clara ligação entre eles, pelo que será de questionar, tendo em conta aspetos como a técnica de execução que se afigura também diferente, se as gravuras foram realizadas em épocas distintas. Referimo-nos, por exemplo, ao eventual antropomorfo de traço mais profundo e mais avivado (Cardoso, D. 2015, p. 278).

O barquiforme da Bouça da Miséria é representado através de um esquema simples preenchido no seu interior por várias linhas gravadas na horizontal. De notar, provavelmente na proa, uma parte sobreleva$\mathrm{da}$, de onde saem dois pequenos traços horizontais (Nash, G., Cardoso, D., Ferreira, E., 2013, p. 48).

Relativamente ao domínio das comparações técnico estilísticas, até ao momento não foram encontrados paralelos na Península Ibérica. Contudo, esta representação rupestre apresenta algumas analogias com algumas representações de barcos da Escandinávia da Idade do Bronze. Como paralelo possível encontram-se semelhanças estilísticas numa embarcação existente no painel V de Evenhus na Noruega (Figura 1of), atribuída ao início da Idade do Bronze, tendo como referência os estudos de Malmer (1981) (citado em Nash, 2008, p. 97).

Se bem que diferente no que caracteriza o "corpo" da embarcação, um dos barquiformes de tipo canoa da Laje da Churra, também apresenta uma proa elevada com um traço horizontal (Figura 10a).

Em suma, perante a escassez de paralelos no Noroeste Peninsular, de sobreposições e de escavações arqueológicas adjacentes ao afloramento gravado, propomos, sob reserva, que o barquiforme da Bouça da Miséria se possa inscrever na Idade do Bronze ou mesmo nos inícios da Idade do Ferro, momento em que se intensificam as navegações na fachada atlântica (Cardoso, D., 2015, p. 236).

Por último, é de registar que no decorrer de estudos mais recentes sobre a temática das embarcações no Monte de S. Romão, a colocação de uma nova hipótese relativamente a um motivo de um barquiforme numa pedra referida por Sarmento (Sarmento, 1905, p. 23). (Figura 10g). Esta representação apresenta algumas analogias com algumas representações de embarcações da Península Ibérica e da Escandinávia. No entanto, em termos estilísticos, é de realçar a sua semelhança com a composição gravada num dos ortostatos do dolmen de Mané Lud (Morbihan, Bretanha francesa), atribuída ao V-IV milenio a.C (Cassen \& alii 2005, p. 362, fig. 16; Cassen, S., 2007) (Figura 1oh) e do barquiforme de forma triangular, do painel 18 da Laje da Churra, a autora propõe uma cronologia situada entre o Calcolítico Final/Idade do Bronze Inicial. Porém não exclui a possibilidade dos barquiformes da Laje da Churra terem sido gravados num momento mais tardio, entre o Bronze Final ou Idade do Ferro (Santos, A., 2014, p. 106).

Assim, perante os dados obtidos e a analogia estilística com as representações de embarcações gravadas no dolmen del Mané Lud, (Morbihan, Bretanha francesa), parece-nos admissível, sob reserva, colocar a hipótese de que o barquiforme em análise possa ter sido gravado entre o IV milénio e o III milénio a.C., embora admitamos poder ser posterior, já que se encontra na Citânia de Briteiros, um povoado dos finais da Idade do Bronze que teve como momento áureo a Idade do Ferro. Somente com a relocalização da pedra gravada e com um exame mais minucioso se poderá confirmar ou invalidar esta proposta pelo que a sua inserção cronológica se mantém em aberto. Resta a expectativa de que seja feita a sua relocalização, para que se possam tecer mais algumas considerações, já que a pedra poderá ter sido reutilizada na estrutura onde se encontra, situação que ocorre recorrentemente em muitos sítios arqueológicos.

Quanto ao domínio das possíveis interpretações para os motivos de embarcações do Monte de S. Romão, cabe-nos perguntar: que tipo de narrativa estará por detrás destas representações? Existirá alguma relação direta com a navegação ou com o curso do rio Ave? Para a Idade do Ferro tem sido defendido que a Citânia de Briteiros, localizada no Monte de S. Romão, constituiu em tempos (...) "um ponto estratégico onde a navegação do Ave, para mercadorias, terminava do alto das suas imponentes muralhas” (...) (Lemos \& Cruz, 2011, p. 48). Será que o espelho de água mantinha as mesmas caraterísticas no momento da gravação das gravuras e na Idade do Ferro? Seria interessante a realização de uma investigação mais aprofundada que clarificasse esta e outras questões. Outra via de abordagem para se tentar compreender a narrativa que se encontra por detrás destes motivos será a de que estas representações poderão estar associadas ao mundo metafó- 
rico e simbólico das comunidades que habitaram o Monte de S. Romão. Nesse sentido, podemos colocar a hipótese de que a representação dos barquiformes poderia estar relacionada com a religiosidade e crenças das comunidades da época, já que o símbolo do barco se encontra presente em várias culturas do mundo, onde a barca é conhecida por ser um símbolo da viagem ou da travessia efetuada pelos vivos ou mortos (Cardoso, D., 2015, p. 283).

\section{CONSIDERAÇÕES FINAIS}

Tendo em conta as embarcações gravadas no Monte de S. Romão (Nash, G., Cardoso, D., Ferreira, E., 2013; Cardoso, D., 2015), consideramos que o número deste tipo de representações é significativo para esta área interior.

Em termos estilísticos devemos dar destaque ao facto de que cada uma das representações apresenta um "desenho" diferente, como se representassem tipos de embarcações distintas, contendo em comum a representação das proas e dos cascos achatados, excetuando o caso do bloco musealizado, cujo casco apresenta uma ligeira curvatura.

A maior representação, com o,59m por o,30 m, localiza-se no afloramento gravado da Bouça da Miséria, a meia vertente, a nordeste do Monte de S. Romão, ainda, dentro da zona especial de proteção da Citânia de Briteiros e próximo de linhas de água e de nascentes, sendo de assinalar o rio Febras, na margem direita do Ave. Tal como já tinha sido mencionado, da Bouça da Miséria é possível usufruir de uma ampla visibilidade, destacando-se no horizonte, para nordeste, a Serra da Cabreira, lugar onde nasce o rio Ave. Os vestígios mais antigos de que temos conhecimento na envolvente da Bouça da Miséria remontam à Pré-história Recente, entre eles algumas mamoas em Donim e na Quinta do Paço (Sarmento, F., 1902a, pp. 19-30), o povoado da Boavista, localizado no sopé do Monte de S. Romão e inserível na Idade do Bronze, bem como vários afloramentos gravados inseríveis na designada Arte Atlântica, correspondente aos finais do IV milénio e parte do III milénio a.C. Perante todo este contexto, e partindo do pressuposto que os afloramentos eram conhecidos pela comunidade ou por uma parte dela, certamente que no ato de gravação todas as "experiências" e "vivências" seriam de certa forma tidas em conta aquando da representação. Nesse sentido, e sendo o Monte de S. Romão portador de uma longa história, a representação do barquiforme da Bouça da Miséria poderá corresponder a uma adição, provavelmente no âmbito de uma revisitação do lugar na Idade do Bronze, já que a primeira fase de gravação deste afloramento corresponde a um momento anterior, mais precisamente ao final do IV milénio a.C., ou entre os finais do Neolítico/Calcolítico.

Para as restantes representações de barquiformes, e uma vez que não detemos todas as informações necessárias para retirar as devidas ilações, poderão estas, ainda, reservar-nos algumas surpresas, devendo assim ser encaradas com muita prudência. As hipóteses interpretativas e as propostas cronológicas apoiaram-se essencialmente nas analogias estilísticas e nas técnicas utilizadas.

Perante os dados adquiridos até ao presente, pode dizer-se que os suportes gravados representam barquiformes pré-históricos, tradicionalmente atribuídos à Idade do Bronze e por vezes com prolongamento até à Idade do Ferro, ou seja, ao I milénio a.C., momento, a partir do qual se intensificam as navegações na fachada atlântica (Bettencourt, A., 2013, p. 167; Cardoso, D., 2015, p. 236). Porém, no caso da pedra gravada mencionada por Martins Sarmento no séc. XIX (Sarmento, F., 1905a, p. 23) poderá equacionar-se a hipótese de que o barquiforme em questão poderá eventualmente fazer recuar a cronologia deste tipo de motivos para um momento anterior, ou seja, entre o IV e o III milénio a.C.. A proposta desta cronologia, baseia-se nas semelhanças estilísticas dos barquiformes gravados no dolmen de Mané Lud (Morbihan, Bretanha francesa) e do barquiforme de formato triangular localizado no painel 18 da Laje da Churra, Viana do Castelo. Admite-se, pois, que esta hipótese é problemática e audaciosa, dado que o suporte onde o motivo se encontra gravado não foi ainda relocalizado.

Quanto à localização destes motivos no Monte de S. Romão, verificou-se que até ao momento os suportes gravados com representações de barquiformes situam-se na vertente média/alta do Monte de S. Romão, a nordeste e sudeste do mesmo. O que terá levado os autores destas manifestações a gravar este tipo de motivos no lado nordeste/sudeste do monte, tendo sido preterido o lado oeste? Poderá a explicação relacionar-se com o contexto circundante? A questão fica em aberto.

Apesar das muitas dúvidas suscitadas e da falta de resposta para muitas delas, este trabalho pretendeu levantar algumas hipóteses e tecer algumas consi- 
derações; mas não nos podemos alhear de que estas suposições têm de ser bem alicerçadas e fundamentadas. Deste modo, as propostas aqui apresentadas devem ser encaradas como hipóteses de trabalho, tendo em conta o teor da base empírica utilizada, mas acima de tudo proporcionar novos caminhos interpretativos assim como promover e ampliar os conhecimentos sobre a arte rupestre pós-paleolítica de ar livre do Noroeste português.

\section{AGRADECIMENTOS}

Giorgos Iliadis, pela realização do modelo em 3D do bloco gravado musealizado e no apoio ao levantamento gráfico do mesmo.

\section{BIBLIOGRAFIA}

ALONSO ROMERO, Fernando (1974) - Hallazgo de un petroglifo con representaciones esquemáticas de embarcaciones de la Edad del Bronce. Zephyrus. Salamanca. 25, pp. 295-308.

BETTENCOURT, Ana (2017) - Gravuras rupestres do Noroeste para além das artes atlânticas e esquemática. In Arnaud, J.; Martins, A. eds. - Arqueologia em Portugal - 2017. Estado da Questão. Lisboa: AAP.

BETTENCOURT, Ana (2013) - O Bronze Final no Noroeste português. Uma rede complexa de lugares, memórias e ações. Estudos Arqueológicos de Oeiras. Oeiras. 20, pp. 145-162.

CARDOSO, Daniela (2011) - Um olhar sobre os últimos trabalhos desenvolvidos, no âmbito da investigação da arte rupestre da Citânia de Briteiros em Guimarães. Acta das IV Jornadas de Jovens em Investigação Arqueológica (JIA 2011), Faro: Universidade do Algarve, pp. 163-168.

CARDOSO, Daniela (2015) - A Arte Atlântica do Monte de S. Romão (Guimarães) no Contexto da Arte Rupestre Pós-paleolítica da Bacia do Ave-Noroeste Português. Vila Real: Universidade de Trás-os-Montes e Alto Douro.

CARDOZO, Mário (1932) - A última descoberta arqueológica na Citânia de Briteiros e a interpretação da «Pedra Formosa». Revista de Guimarães. Guimarães. 42: 1-2, p. 22.

CARDOZO, Mário (199o) - Citânia de Briteiros e Castro de Sabroso. Guimarães: Sociedade Martins Sarmento ( $8^{\circ}$ edição), pp. 9-10.

CASSEN, Serge. (2007) - Le Mané Lud en images. Interprétations de signes graves sur les parois de la tombe à couloir néolithique de Locmariaquer (Morbihan). Gallia Préhistoire. Paris. 49, pp. 197-258.

CASSEN, Serge; LEFEÉBVRE Benoit; LASTRES, Jacobo; COLLIN, Clément (2005): Le Mané Lud en sauvatage (Locmariaquer, Morbihan): enregistrement et restitution des signes graves dans une tombe à couloir néolithique. L'Anthropologie. Paris. 109, pp. 325-384.

COSTA, Francisco (2007) - A gestão das Águas Públicas O caso da Bacia Hidrográfica do Rio Ave no período 1902-1973. Braga: Universidade do Minho.

COSTAS GOBERNA, Fernando; PEÑA SANTOS, António

(2006) - Los barcos de los Petroglifos de Oia. Los tesoros del hechicero y una nueva embarcación. Glaucopis. Vigo. 12, pp. 277-292.

FERREIRA, Narciso, DIAS, Graciete, MEIRELES, Carlos \& BRAGA Maria (2000) - Carta Geológica de Portugal. Notícia Explicativa da Folha 5-D. Braga: Instituto Geológico e Mineiro.

GARCIA ALEN, Alfredo; PENA SANTOS, António (1980) - Grabados rupestres de la provincia de Pontevedra. A Coruna: Fundación Barrié de la Maza.

GELL, Alfred (1998) - Art and Agency: An Anthropological Theory. Oxford, Clarendon Press.

GOLDHAHN, Joakim; LING, Johan (2013) - The Oxford Handbook of European Bronze Age, Chapter: 15. - Oxford University Press, pp. 270-29o.

INGOLD, Thomas (2000) - The Perception of the Environment. Essays on Livelihood, Dwelling and Skill. London and NewYork, Routledge.

LEMOS, Francisco; CRUZ, Gonçalo (2011) - Citânia de Briteiros - Povoado Proto-histórico / The Protohistoric Settlement. Guimarães: Sociedade Martins Sarmento.

LING, Joan; STOSGALE, Zofia A. (2015) - Representations of oxhide ingots in Scandinavian rock art: the sketchbook of a Bronze Age traveller. Antiquity, 89: 343, pp. 191-207.

NASH, George (2008) - Northern European hunter/fisher/ gatherer and Spanish Levantine rock-art: A study in performance, cosmology and belief. Trondheim: NTNU.

NASH, George, CARDOSO, Daniela \& FERREIRA, Eduardo (2013) - What lies beneath? Understanding the artistic stratification of Citânia, an Iron Age proto-hillfort in Northern Portugal. Current World Archaeology Magazine. London. 6o, pp. 44-48.

SANTOS, Ana (2013) - The rock engravings of Laje da Churra, Paçô, Carreço, Viana do Castelo/As gravuras rupestres da Laje da Churra, Paçô, Carreço, Viana do Castelo. In A.M.S. Bettencourt. The Prehistory of the Northwestern Portugal / A Pré-História do Noroeste Português, Territórios da Pré-História em Portugal. Vol.2. Braga/Tomar: CITCEM/CEIPHAR, pp. 196-200.

SANTOS, Ana (2014) - A Lage da Churra (Carreco, Viana do Castelo). Estudo Monográfico de um Lugar Gravado. Braga: Universidade do Minho. 
SANTOS-ESTEVEZ, Manuel; BETTENCOURT, Ana (2017) - O conjunto de gravuras rupestres de Santo Adrião (Caminha, Portugal). Embarcações, armas, cavalos e ex-votos. in J. M. ARNAUD; A. MARTINS eds. - Arqueologia em Portugal 2017 - Estado da Questão. Lisboa: Associação de Arqueólogos Portugueses.

SARMENTO, Francisco (1901) - Materiais para a arqueologia do concelho de Guimarães. Revista de Guimarães. Guimarães. 18: 1-2, p. 19.

SARMENTO, Francisco (1902) - Materiais para a arqueologia do concelho de Guimarães. Revista de Guimarães. Guimarães. 19: 1, pp. 22-23.
SARMENTO, Francisco (1904) - Materiais para a arqueologia do concelho de Guimarães. Citânia. Revista de Guimarães. Guimarães. 21: 2, p. 61.

SARMENTO, Francisco (1905) - Materiais para a arqueologia do concelho de Guimarães. Citânia. Revista de Guimarães. Guimarães. 22: 1-2, p. 17-23.

SARMENTO, Francisco (1933) - Dispersos: colectânea de artigos publicados, desde 1876 a 1899, sobre arqueologia, etnologia, mitologia, epigrafia e arte pré-histórica: obra comemorativa do $1^{\circ}$ centenário do nascimento do autor. Coimbra: Universidade de Coimbra.

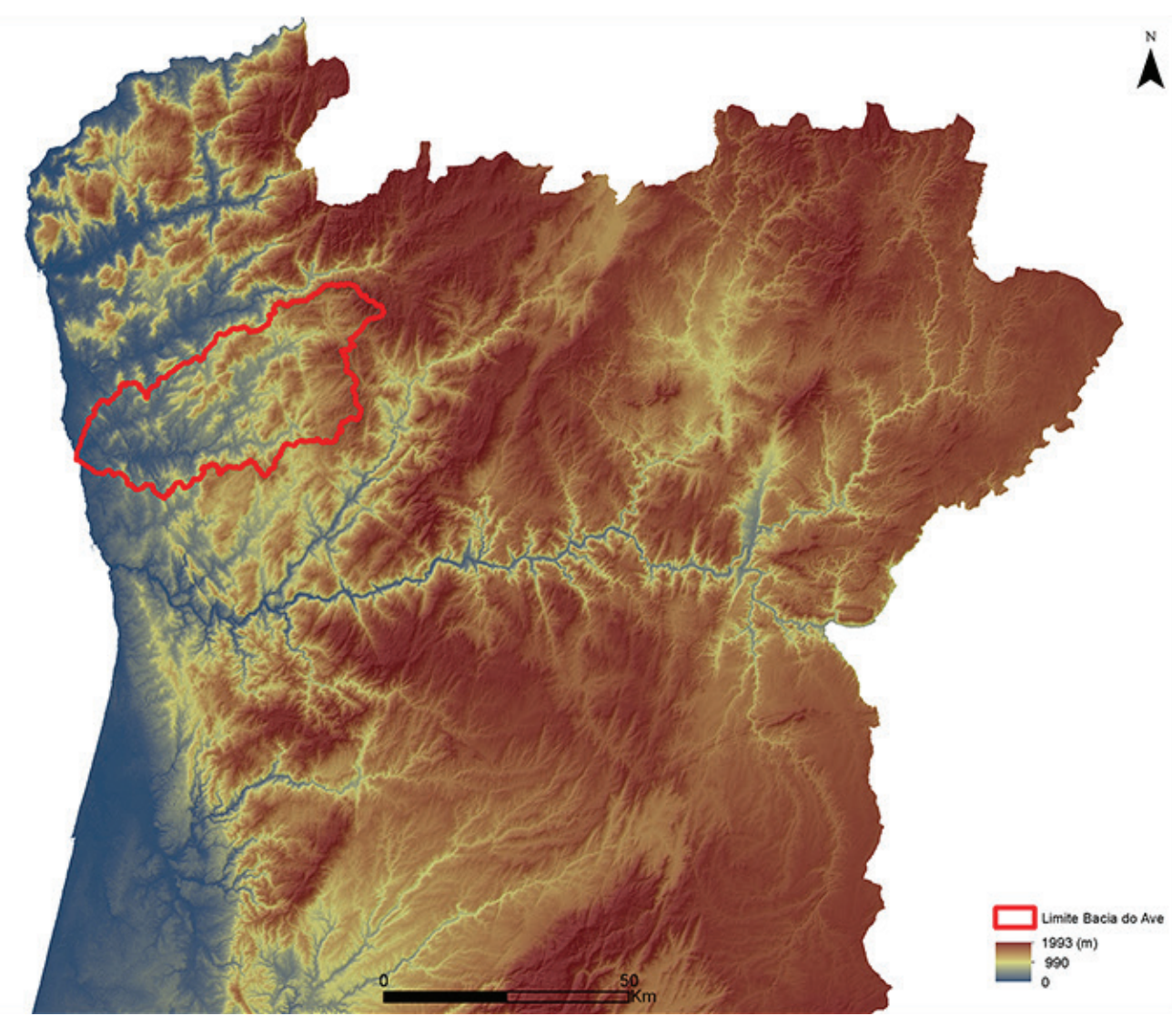

Figura 1 - Mapa de Portugal com a localização da bacia do Ave (Cardoso, D., 2015, p. 27). 


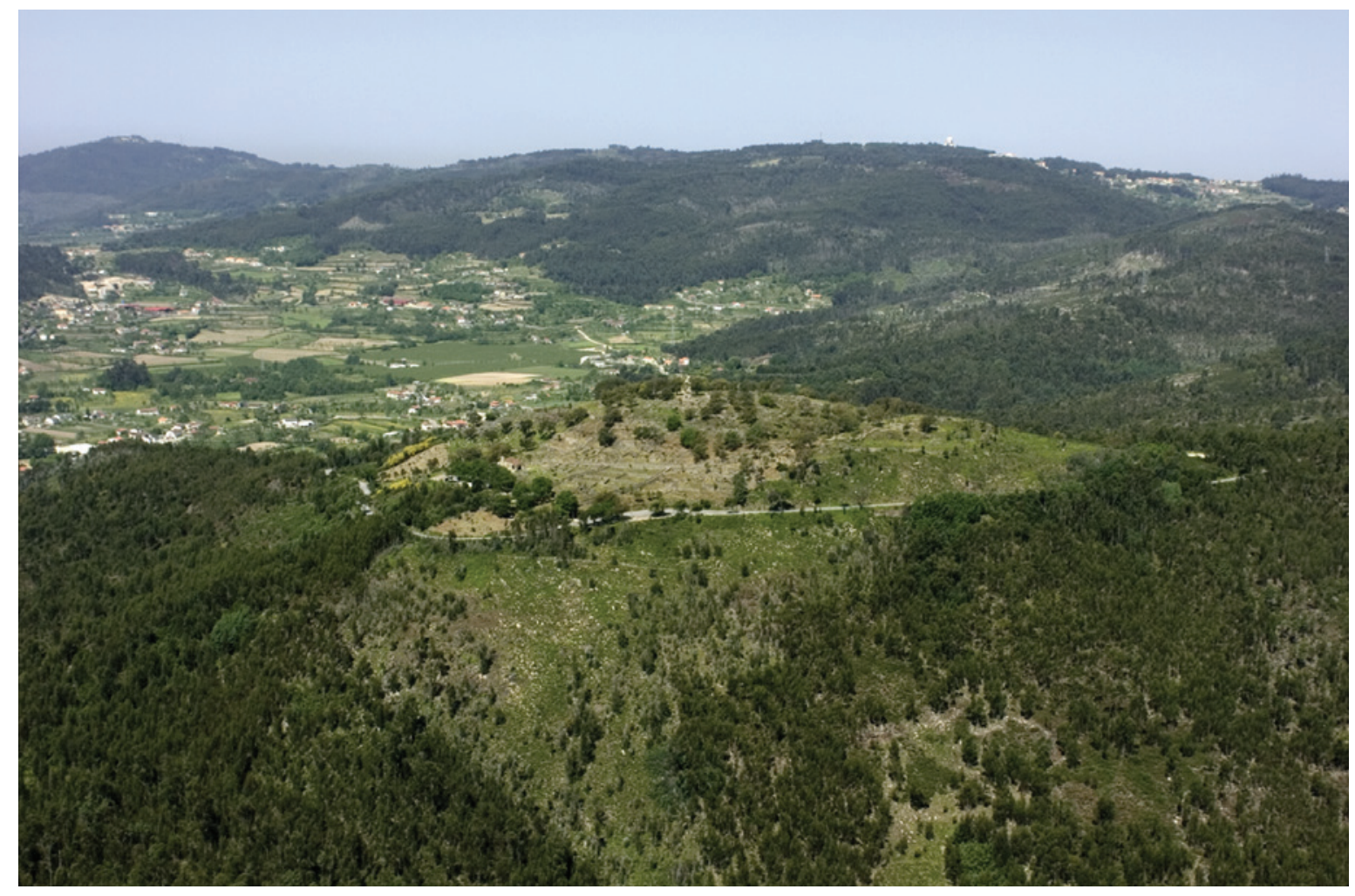

Figura 2 - Enquadramento do Monte de S. Romão face ao vale do Ave (Fonte: SMS).

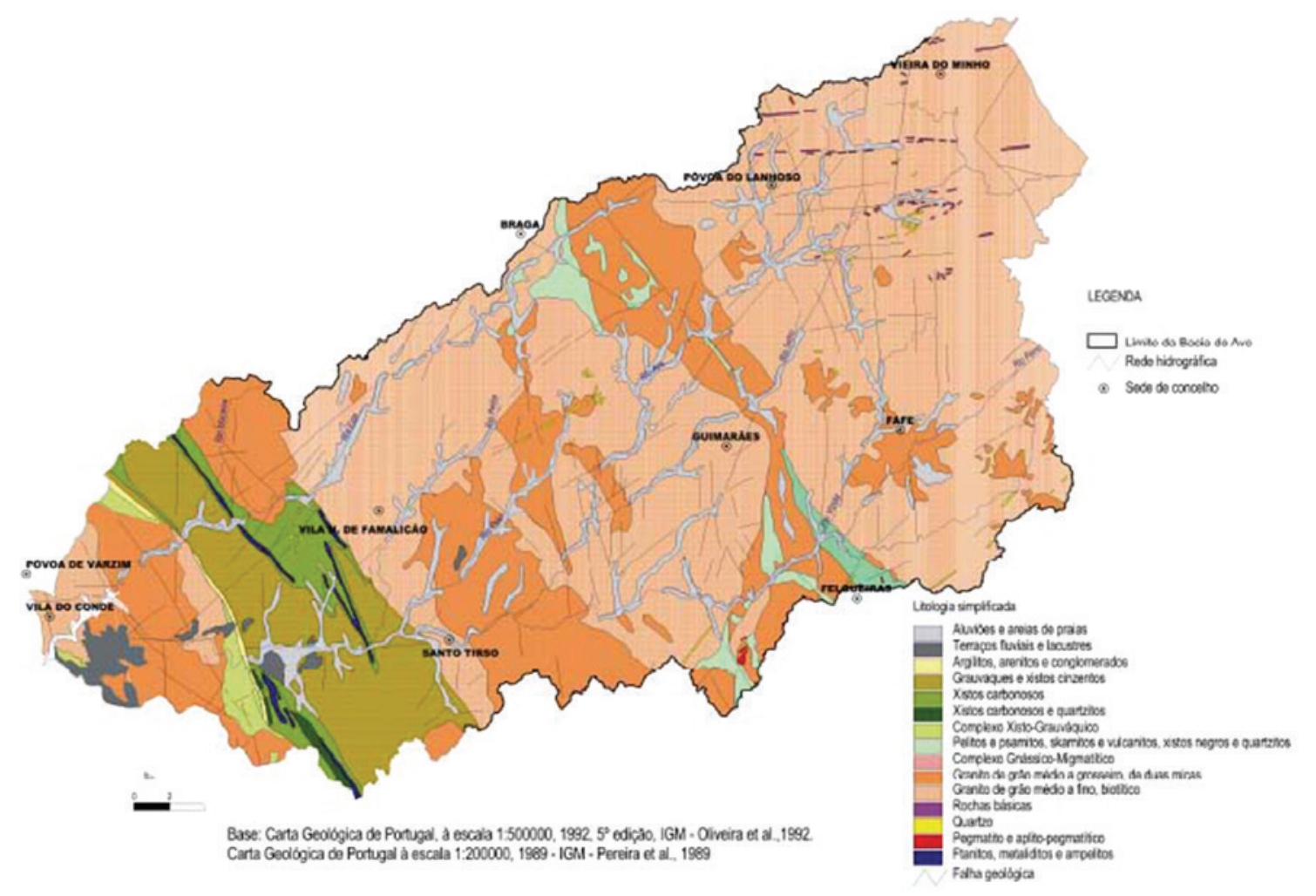

Figura 3 - Mapa geológico da bacia hidrográfica do rio Ave. O relevo é assinalado com cores diferenciadas (Fonte: Costa, F., 2007, p. 139, fig. 26). 


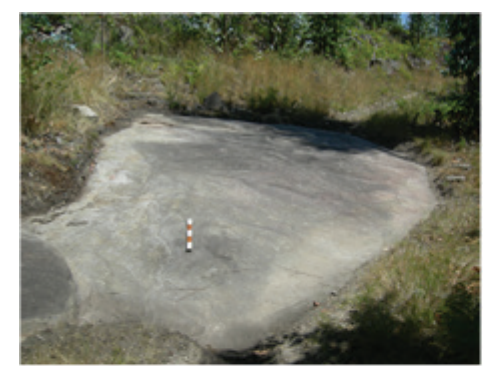

A

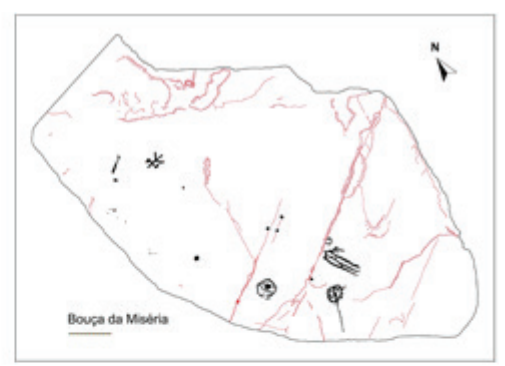

B

\section{C}

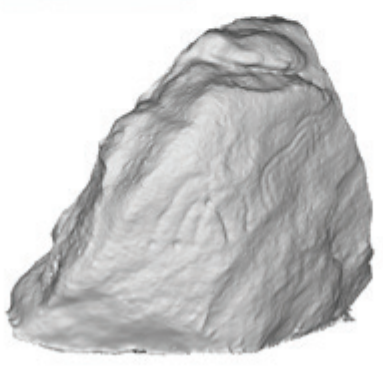

Figura 4- A - Vista geral do afloramento gravado da Bouça da Miséria, Monte de S. Romão (Cardoso, D., 2015, p. 173); B - Decalque do afloramento gravado da Bouça da Miséria, Monte de S. Romão (Cardoso, D., 2015, p.176); C-Vista geral do modelo em $3 \mathrm{D}$ do bloco gravado com o motivo de um barquiforme, exposto no Museu Arqueológico da Sociedade Martins Sarmento (Fonte: Giorgos Iliadis).
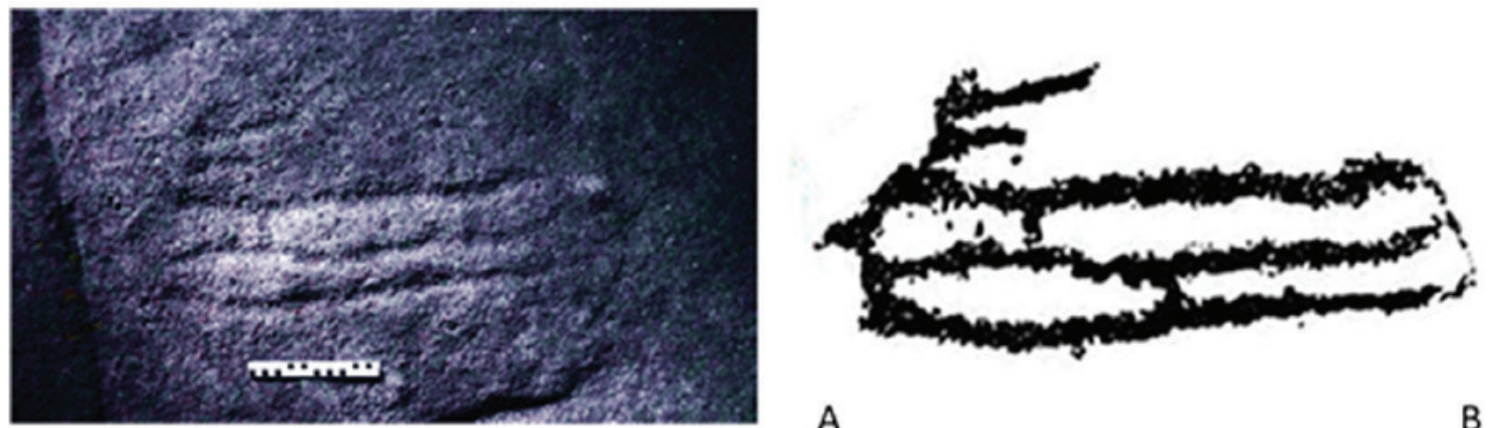

A

Figura 5-A - Fotografia de pormenor do barquiforme da Bouça da Miséria, Monte de S. Romão, através da utilização de luz rasante (Cardoso, D., 2015, p. 218); B - Pormenor do barquiforme proveniente do decalque da Bouça da Miséria, Monte de S. Romão (Cardoso, D., 2015, p. 176). 


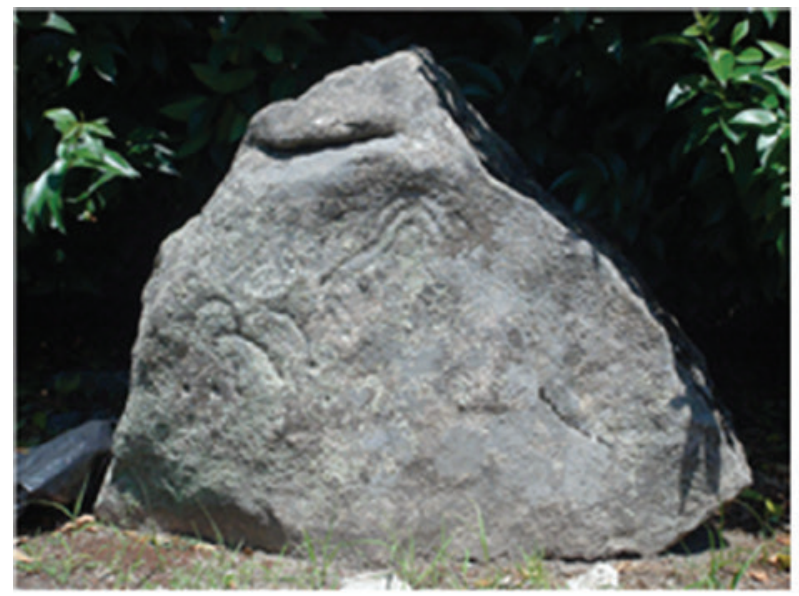

A

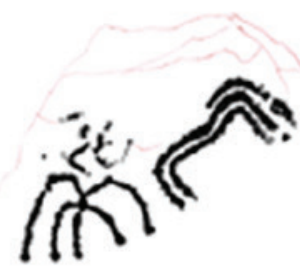

B

Figura 6 - A - Vista geral do bloco gravado proveniente do Monte de S. Romão e exposto no Museu Arqueológico da SMS; B - Decalque do bloco gravado proveniente do Monte de S. Romão e exposto no Museu Arqueológico da SMS.

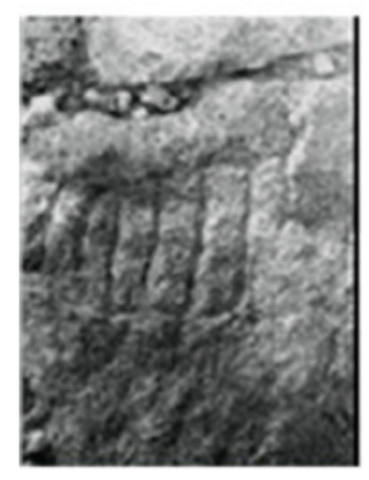

A

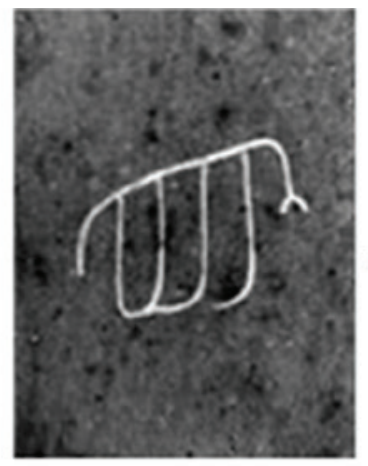

B

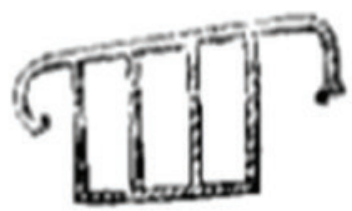

C
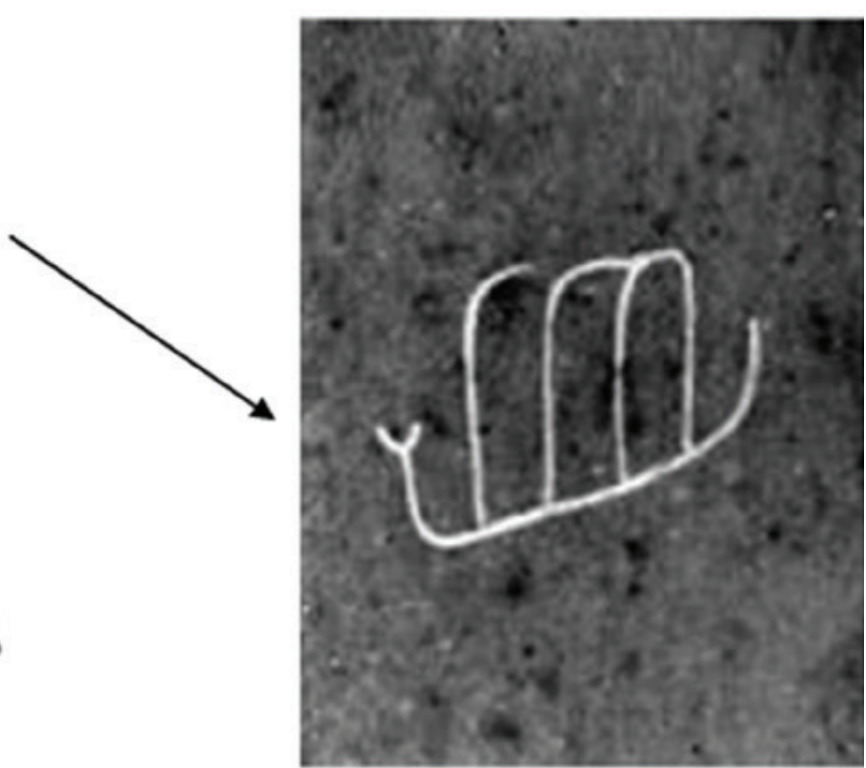

D

Figura 7 - A - Fotografia de Sarmento (Fonte: Fototeca da SMS, Est. XV); B - Fotografia de Sarmento (Fonte: Citânia - Álbum de fotografias - 2, 1992, Est. XIV); C - Desenho de Martins Sarmento (Fonte: Sarmento, F., 1905, p. 23); D - Fotografia de Sarmento invertida (Fonte: adaptado de Citânia - Álbum de fotografias - 2, 1992, Est. XIV). 


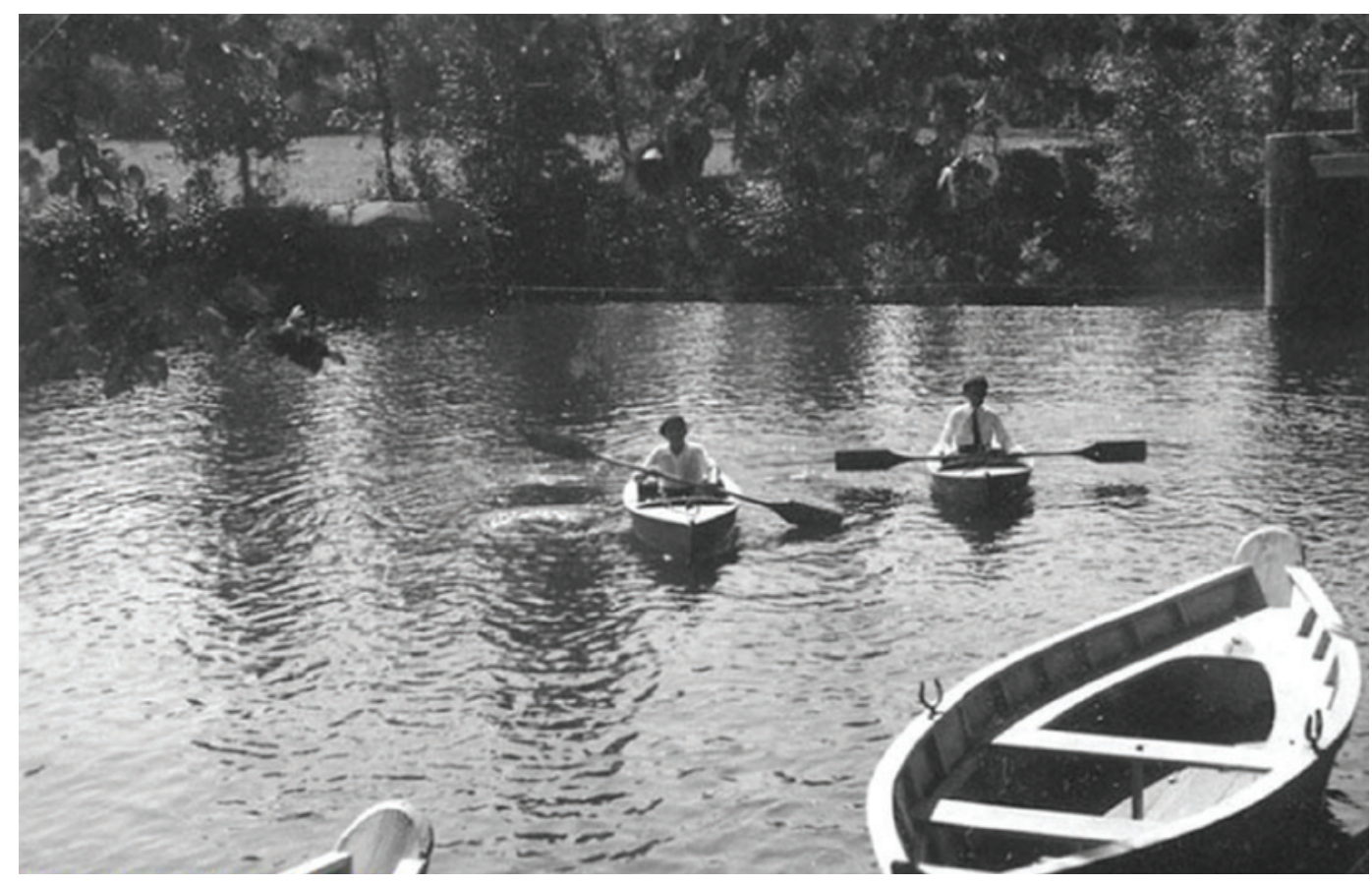

Figura 8 - Vista de um troço do rio Ave e suas embarcações nos anos zo do séc. XX (Fonte: Fototeca da SMS).
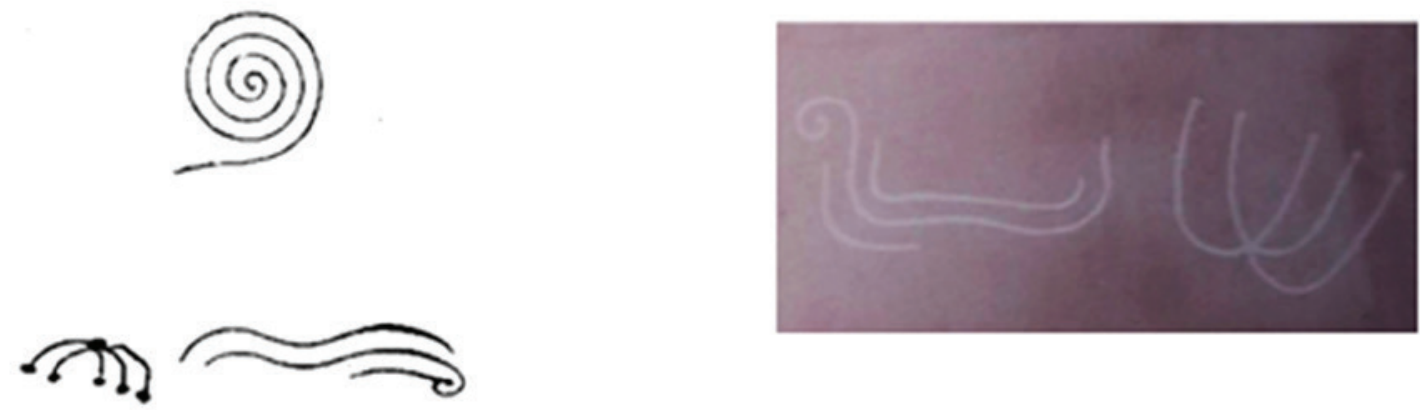

A

B
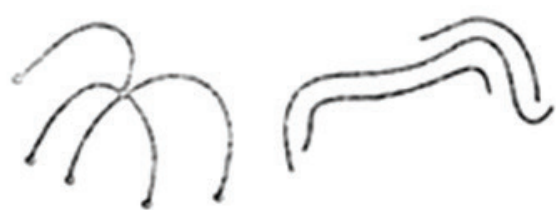

C

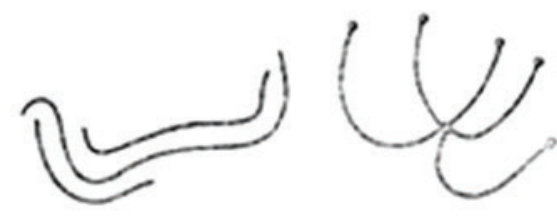

D

Figura 9-A - Desenho de Sarmento (Fonte: Sarmento, F., 1904, pág. 61); B - Fotografia de Sarmento (Fonte: Citânia - Álbum de fotografias - 1, 1992, Est. XVII); C - Desenho de Mário Cardozo (Fonte: Cardozo, M., 1932, fig. 15, p. 22); D - Desenho adaptado de Mário Cardozo e colocado em posição invertida (Fonte: Cardoso, D., 2015, p. 181). 


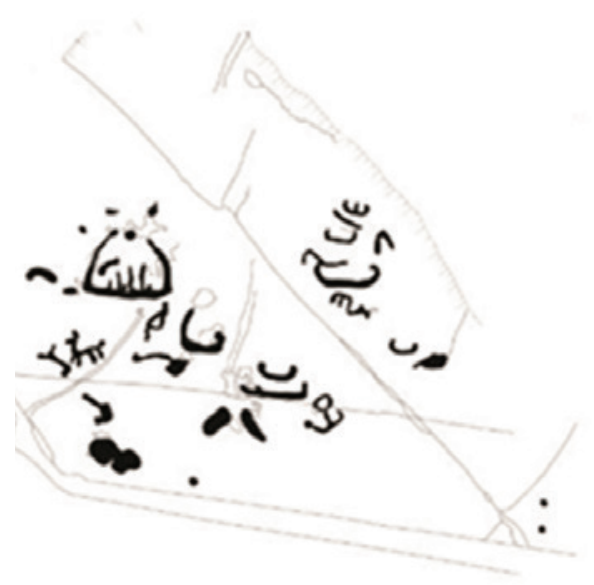

A

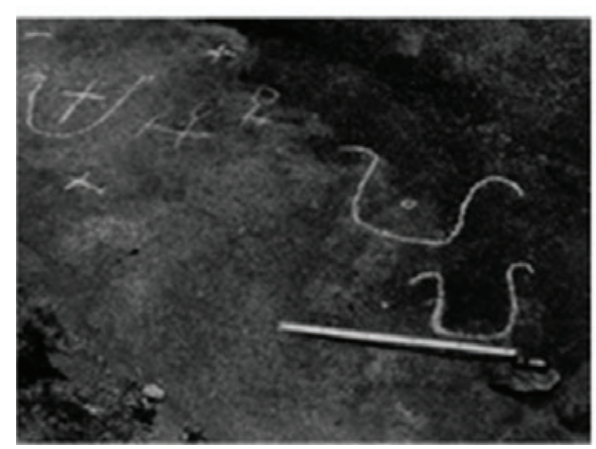

C

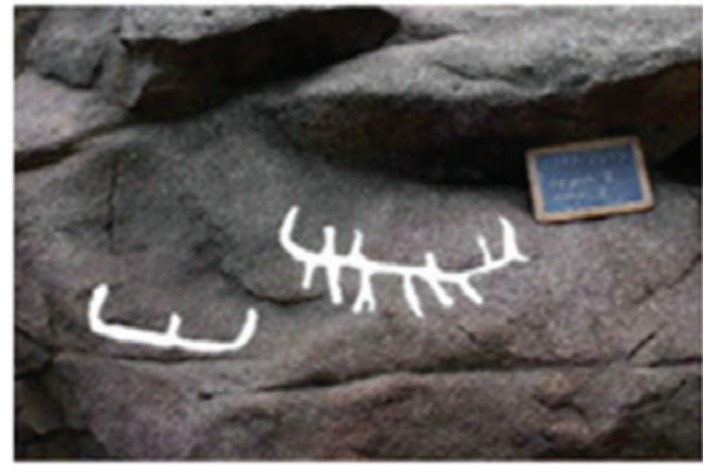

B

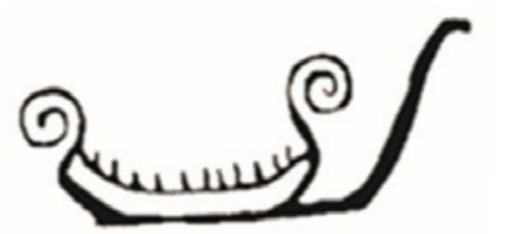

D-1

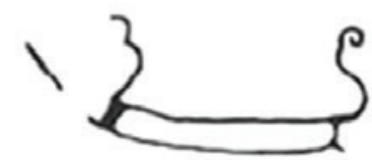

D-2

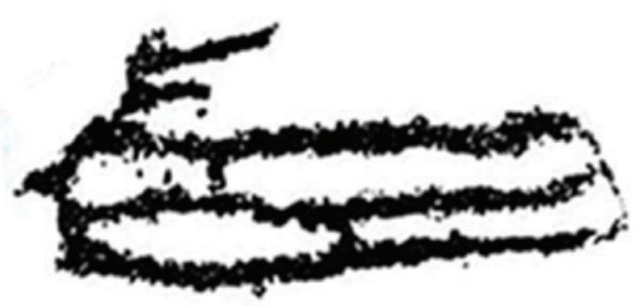

E

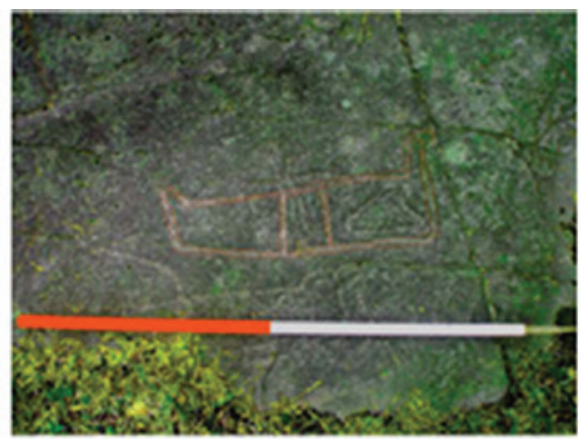

F

G
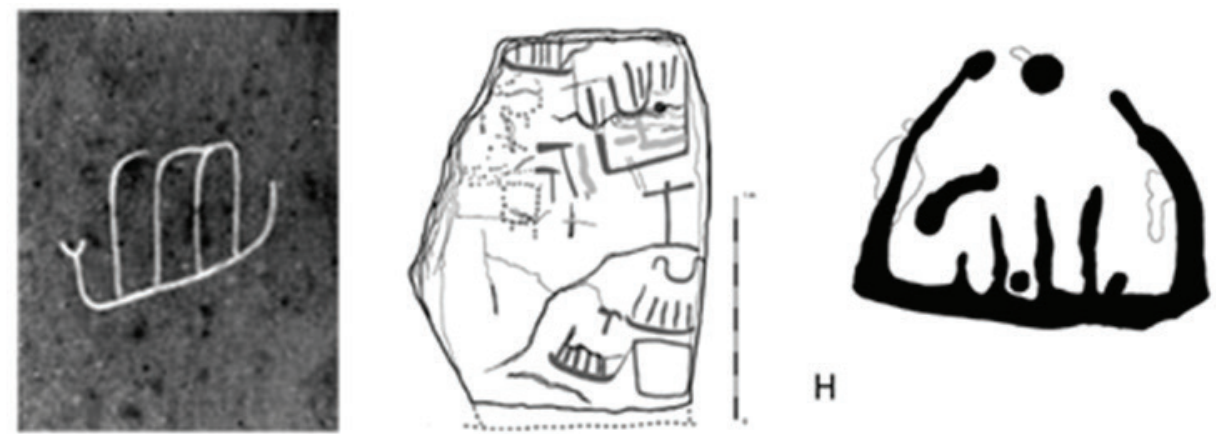

H

Figura 10 - A - Barquiformes da Laje da Churra (Fonte: Santos, A., 2014, p. 71); B - Barquiformes de Santo Adrião (Fonte: Santos-Estévez \& Bettencourt, A., 2017, p. 1066, adaptado); C - Barquiformes de Borna (Fonte: Alonso Romero, 1974, p. 296); D-1, D-2 - Barquiformes Tanumm, Bohuslãn, Suécia (Goldhahn, J. \& Ling, J., 2013, p. 276, adaptado); E - Detalhe adaptado do decalque do barquiforme da Bouça da Miséria, Monte de S. Romão (Cardoso, D., 2015, p. 176); F- Barquiforme do painel V de Evenhus na Noruega (Nash, G., 2008, p. 97); G - Fotografia de Sarmento invertida (Fonte: Adaptada do álbum fotografias de Martins Sarmento, nº2, 1992, Est. XIV); H - Barquiforme Grabados del dolmen de Mané Lud, Morbihan, Bretanha francesa (Cassen \& alii. 2005, p. 362); I - Barquiforme da Laje da Churra, Viana do Castelo (Santos, A., 2014, p. 72). 



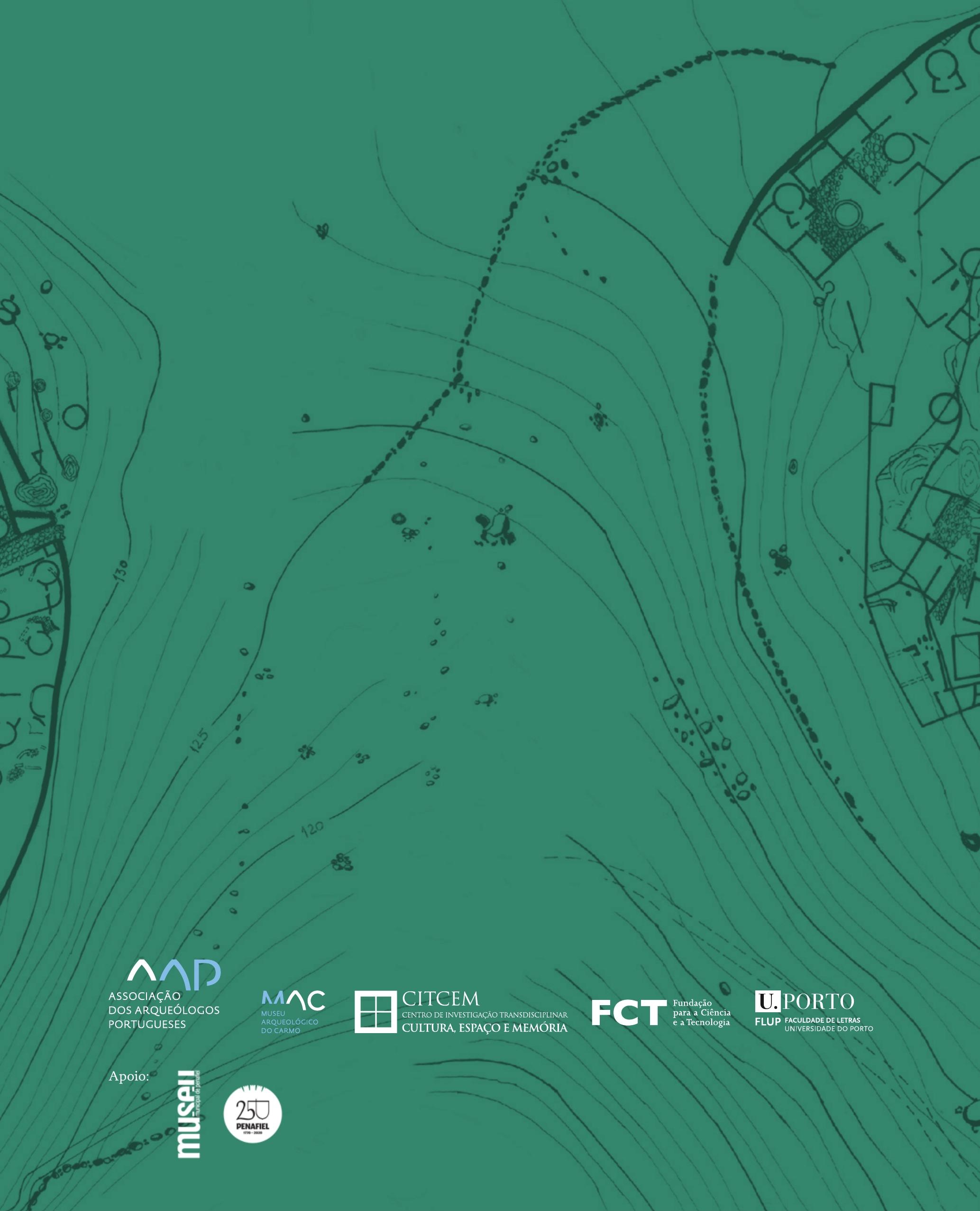

